
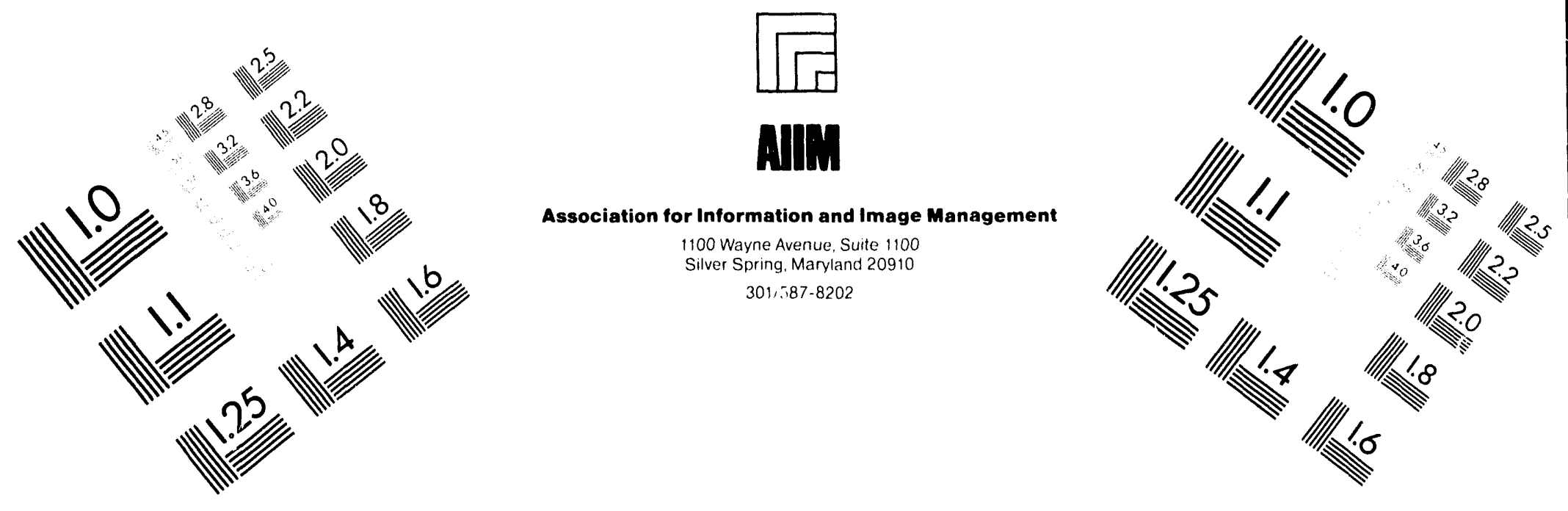

\title{
Centimeter
}

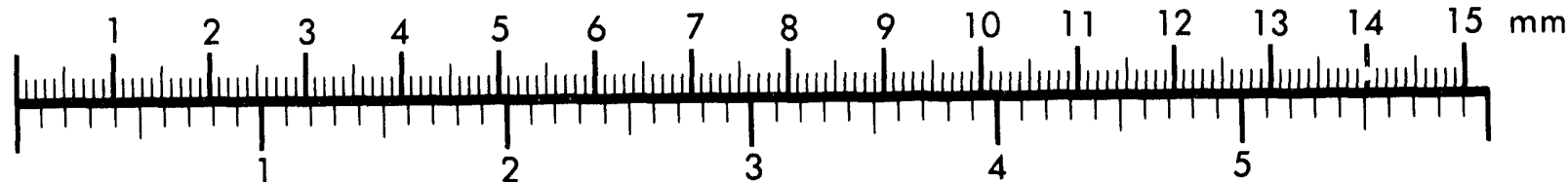
Inches
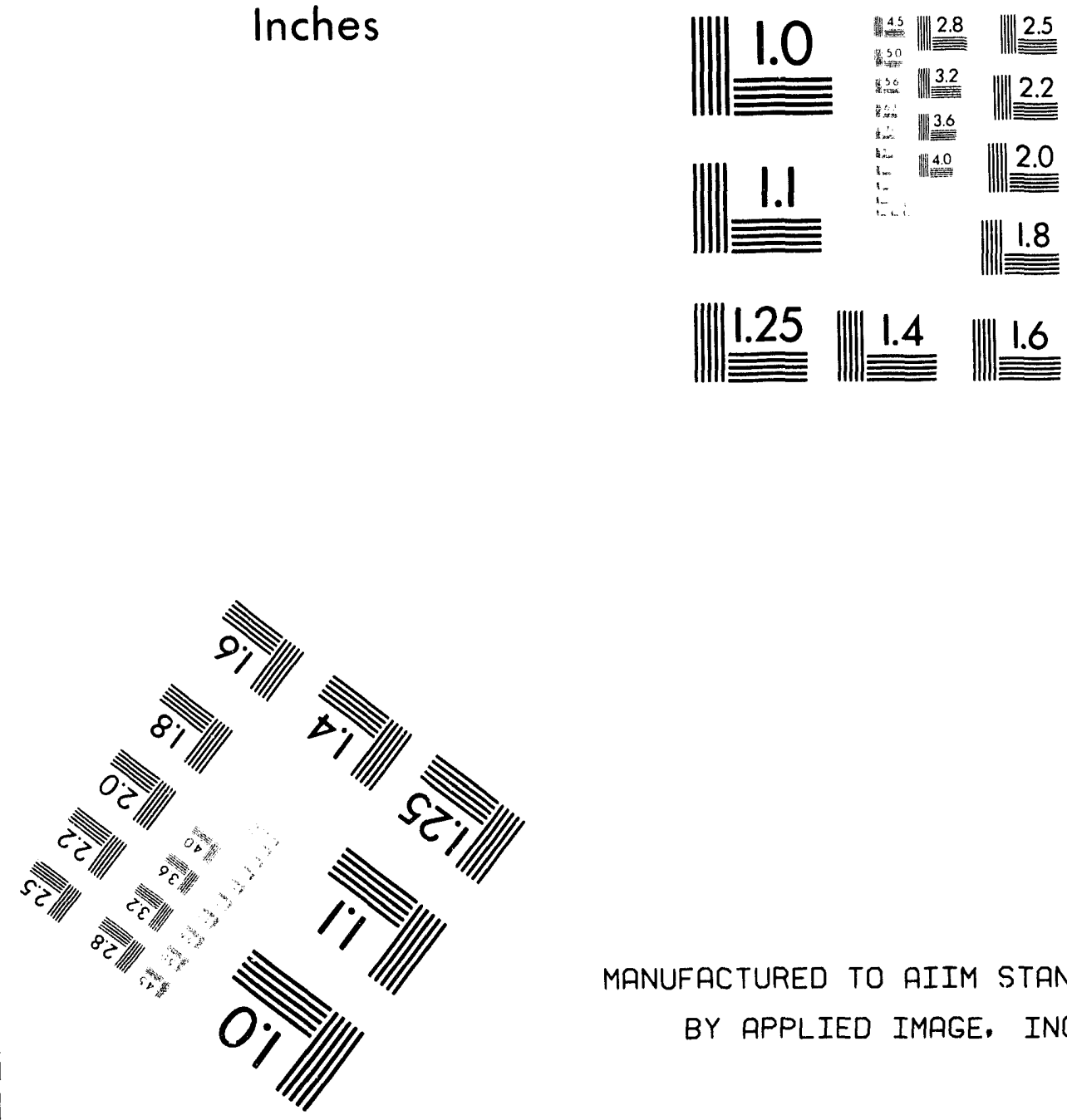

MANUFACTURED TO AIIM STANDARDS

BY APPLIED IMAGE. INC.

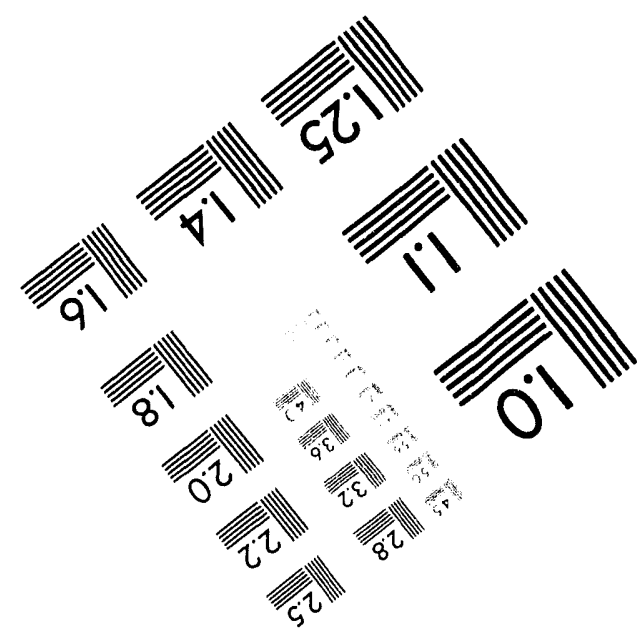



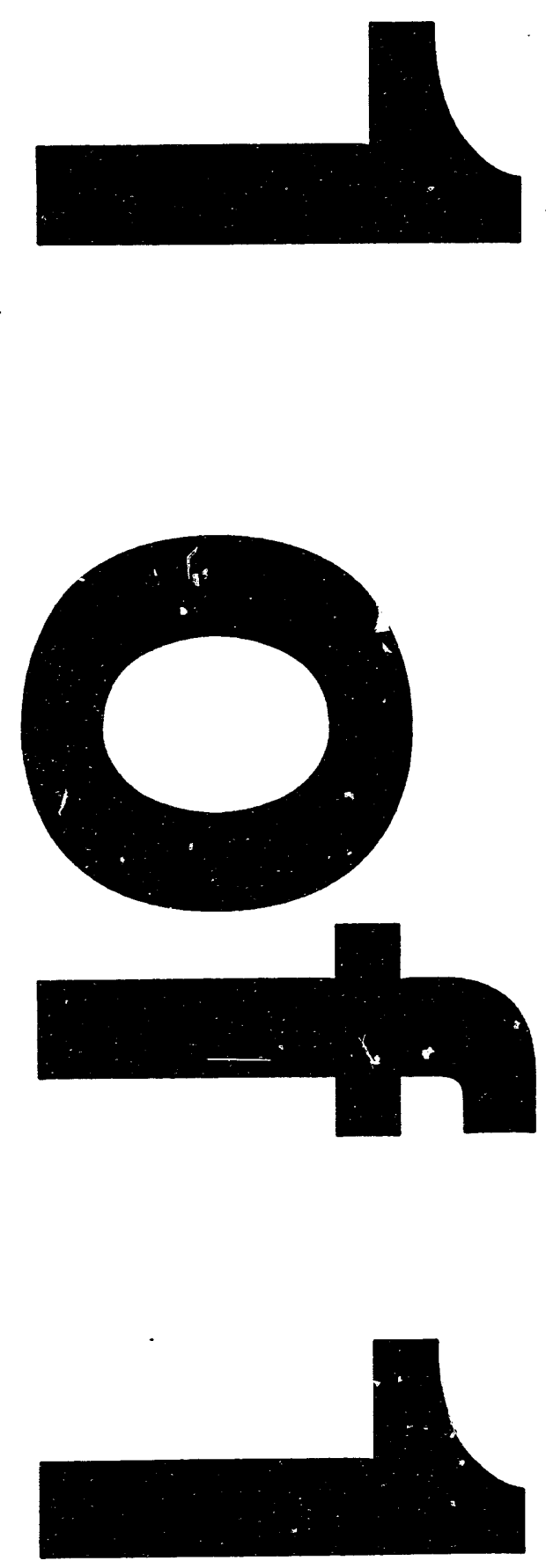


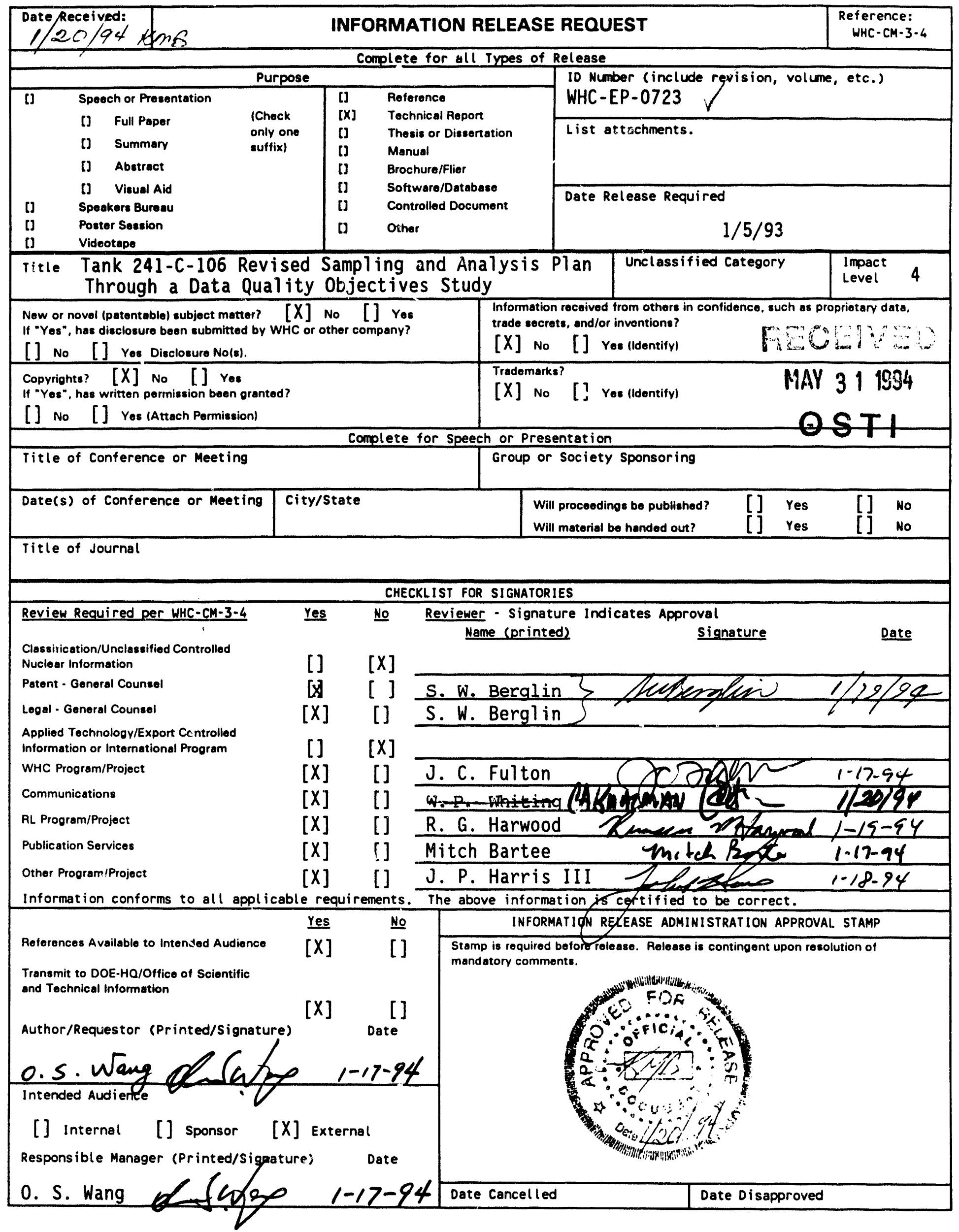




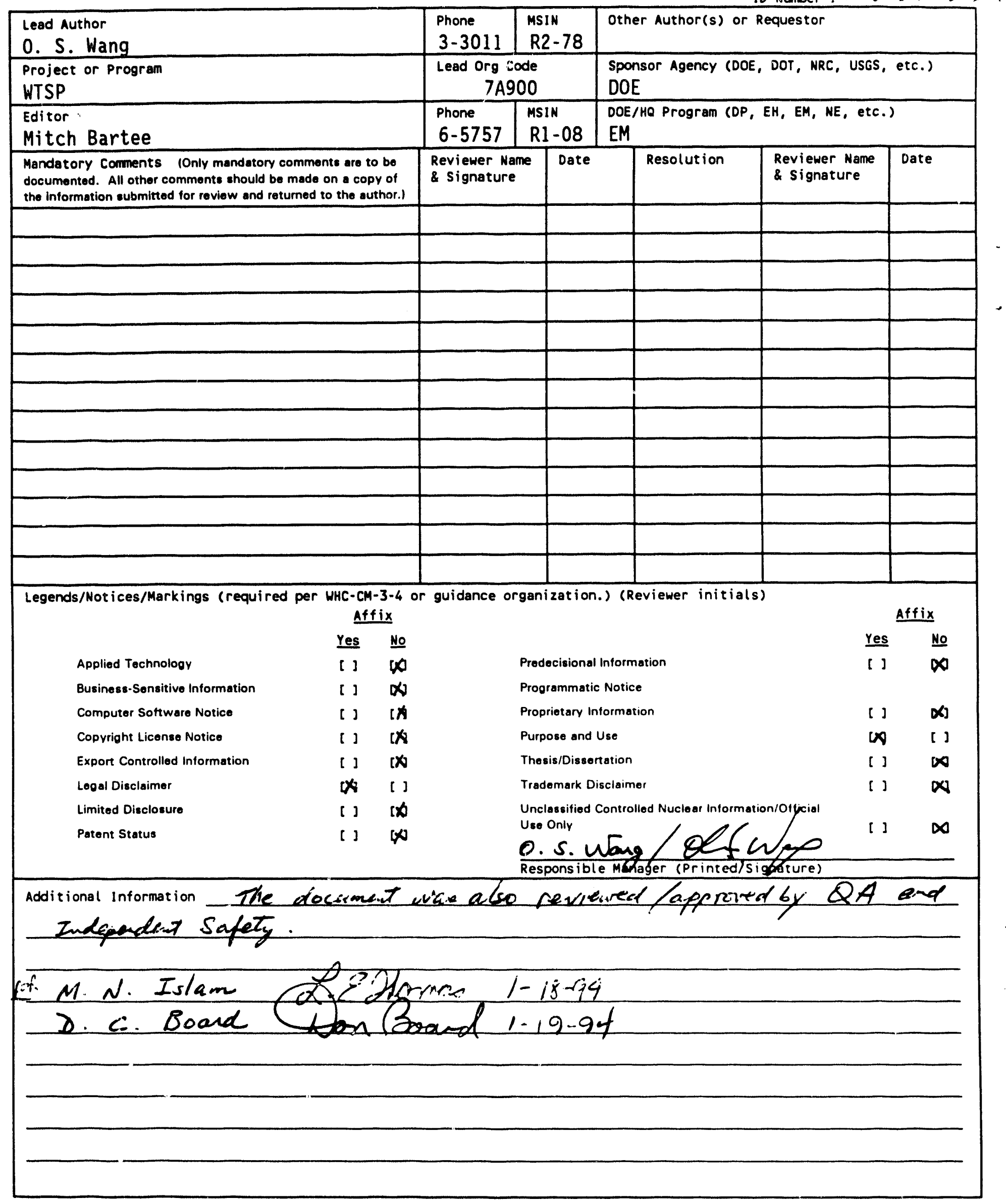




\section{Tank 241-C-106 Sampling Data Requirements Developed Through the Data Quality Objectives (DQO) Process}

O. S. Wang

K. E. Bell

Westinghouse Hanford Company

C. M. Anderson

M. S. Peffers

B. A. Pulsipher

J. L. Scott

Pacific Northwest Laboratory

Date Published

January 1994

Prepared for the U.S. Department of Energy Office of Environmental Restoration and Waste Management

\section{(W) Westinghouse P.O. Box 1970 \\ Hantord Company Richland, Washington 99352 \\ Hanford Operations and Engineering Coritractor for the \\ U.S. Department of Energy under Contract DE-AC06-87RL10930}

Approved for Public Release

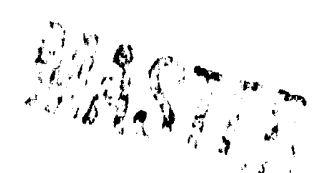




\section{ACKNOWLEDGEMENTS}

The authors of this report would like to acknowledge the support from Dan Goodman of DOE-HQ and Stan Blacker of MACTEC who provided indispensable guidance and support to this effort. Staff from other TWRS functionsl elements who provided valuable inputs include Cherri Defigh-Price, John Harris, Mark Henderson, Tom May, Harry Babad, and Julian Hill. Discussions with modelers and laboratory personnel like Tom Banders and Bill Winters were very beneficial to the completion of this report.

Appreciation is also extended to PNL staff who provided support to this report: Tom Wood, Susan McKinley, Greg Whyatt, Lynette Jagoda, and Jason Daume. Finally, we would like to thank Chris Forbes and Mitch Bartee of BSCR for their excellent editorial support. 


\section{EXECUTIVE SUMMARY}

The rate of heat generation for tank 241-C-106 at the Hanford Site is estimated at more than $100,000 \mathrm{Btu} / \mathrm{h}$. The heat is generated primarily from the radioactive decay of ${ }^{90} \mathrm{Sr}$ waste that was inadvertently transferred into the tank in the late 1960 s. If proper tank cooling is not maintained for this tank, heat-induced structural damage to the tank's concrete shell could result in the release of nuclear waste to the environment. Because of high-heat concerns in January 1991, tank 241-C-106 was designated as a "Watch List" tank and deemed as a Priority 1 safety issue. Waste Tank Safety Program (WTSP) is responsible for the resolution of this safety issue.

Although forced cooling is effective for short term, the long-term resolution for tank cooling is waste retrieval. Single-Shell Tank Retrieval Project (Retrieval) is responsible for the safe retrieval and transfer of radioactive waste from tank 241-C-106 to a selected doubleshell tank. TPA Milestone M-07-00 requires retrieval to be started by October 1997. Westinghouse Hanford Company and the Department of Energy have moved the deadline ahead one year in order to start retrieval by October 1996 as a Safety Initiative (6d). To support this aggressive schedule, Safety Initiative 6a requires retrieval-related designs be start by September 1993.

This Data Quality Objective (DQO) study is an effort to determine engineering and design data needs for WTSP and assist Retrieval in designing contingency action retrieval systems. The 7-step DQO process is a tool developed by the Environmental Protection Agency (EPA) with a goal of identifying needs and reducing costs. This report discusses the results of two DQO efforts for WTSP and Retrieval. The key data needs to support WTSP are thermal conductivity, permeability, and heat load profile. For the Retrieval support, there are nine and three data needs identified, respectively, for retrieval engineering system design and HVAC system design. The updated schedule to drill two core samples using rotary mode is set for March 1994. The analysis of the sample is expected to be completed by September 1994.

The design effort for the retrieval and contingency safety systems was initiated in August 1993 to meet a DOE Safety Initiative requirement. The designs use conservative assumptions and data based on past sluicing and operating experiences. Successful past sluicing activities provide a high confidence level in the current design effort without prior knowledge of the samples results.

Due to the physical limitations and available raiser in tank 244-C-106, only two full length (4 segments each) samples will be obtained using rotary mode. The sample analysis results will be compared to the current design data based on an uncertainty study on sampling and data analysis error tolerance addressed in this study. The conservatively selected design parameters minimize the risk of modifying ongoing system designs. Even in an unlikely event that the upcoming sample analysis results in design modification, the impact could be a minor schedule delay in retrieval that would not be related to safety of the public or workers. 


\section{CONTENTS}

1.0 INTRODUCTION $\ldots \ldots \ldots \ldots \ldots \ldots \ldots \ldots \ldots \ldots \ldots \ldots \ldots \ldots \ldots \ldots \ldots .11$

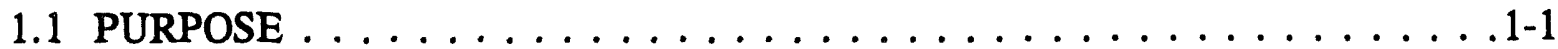

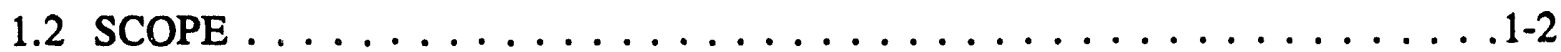

1.3 DATA QUALITY OBJECTIVES BACKGROUND $\ldots \ldots \ldots \ldots \ldots \ldots$

2.0 BACKGROUND ON 241-C-106 CORE SAMPLING DQO $\ldots \ldots \ldots \ldots \ldots .2-1$

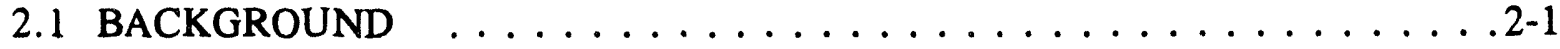

2.2 TANK $241-\mathrm{C}-106$ DQO ASSUMPTIONS $\ldots \ldots \ldots \ldots \ldots \ldots \ldots .2-2$

3.0 PROGRAM DATA NEEDS $\ldots \ldots \ldots \ldots \ldots \ldots \ldots \ldots \ldots \ldots \ldots \ldots$

3.1 FUNCTIONAL AREA DATA NEEDS $\ldots \ldots \ldots \ldots \ldots \ldots \ldots$ 3-1

3.1.1 Waste Tank Safety Program $\ldots \ldots \ldots \ldots \ldots \ldots \ldots . \ldots \ldots$.1

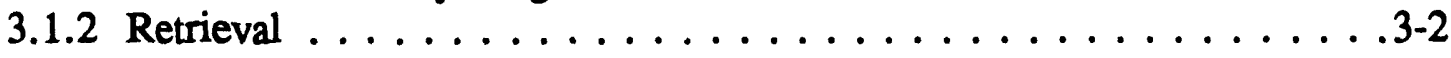

3.1.3 Other User Groups . . . . . . . . . . . . . . . .3-3

3.2 SUMMARY OF DATA NEEDS $\ldots \ldots \ldots \ldots \ldots \ldots \ldots \ldots \ldots \ldots$

3.3 DECISION RULES AND ERROR TOLERANCES $\ldots \ldots \ldots \ldots \ldots \ldots$. . . . .

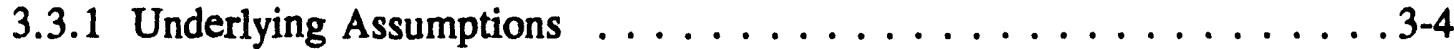

3.3.2 Error Tolerances $\ldots \ldots \ldots \ldots \ldots \ldots \ldots \ldots . \ldots \ldots$. . . . . . . . .

4.0 SUMMARY OF RESULTS FOR TANK $241-\mathrm{C}-106 \ldots \ldots \ldots \ldots \ldots \ldots$. $\ldots \ldots$

4.1 RESULTS . . . . . . . . . . . . . . . . . . 4-1

4.2 IMPLEMENTING RESUITS $\ldots \ldots \ldots \ldots \ldots \ldots \ldots \ldots \ldots$. . . . . .

5.0 TANK 241-C-106 REVISED SAMPLING AND ANALYSIS PLAN $\ldots \ldots \ldots \ldots$ 5-1

5.1 INTRODUCTION $\ldots \ldots \ldots \ldots \ldots \ldots \ldots \ldots \ldots . \ldots \ldots$. . . . . . . . .

5.1.1 Requirements, Procedures, and Definitions . . . . . . . . 5-1

5.2 CORE SAMPLE ANALYSES $\ldots \ldots \ldots \ldots \ldots \ldots \ldots \ldots$. $\ldots \ldots \ldots$

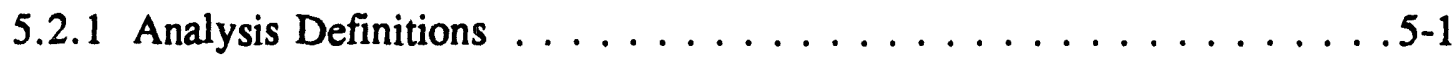

5.2.2 Core Sample Analysis . . . . . . . . . . . . . . 5-2

6.0 REFERENCES . . . . . . . . . . . . . . . . . . . .6-1

APPENDICES

A INDEPENDENT WASTE TANK SAFETY PROGRAM

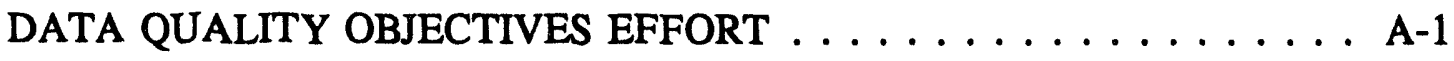

B IDENTIFICATION OF MEASURES FOR RETRIEVAL PROJECT $\ldots .$. B-1 


\section{LIST OF FIGURES}

5-1 Cores $1 \& 2$ Test Plan Flowchart $\ldots \ldots \ldots \ldots \ldots \ldots \ldots \ldots \ldots$

5-2 Cores 1 \& 2 Physical and Segment-Level Analyses . . . . . . . . . . . 5-7

$5-3$ Cores $1 \& 2$ Liquid Composite Analyses . . . . . . . . . . . 5-8

$5-4$ Cores $1 \& 2$ Core Composite Analyses $\ldots \ldots \ldots \ldots \ldots \ldots \ldots \ldots \ldots$ 5-9

\section{LIST OF TABLES}

3-1 Confidence Statements for Thermal Conductivity Mean . . . . . . . . . . 3-6

B-1 Retrieval's Engineering and Design Data Needs for SST $241-C-106 \ldots \ldots \ldots \ldots \ldots \ldots \ldots$. . . . . . . . .

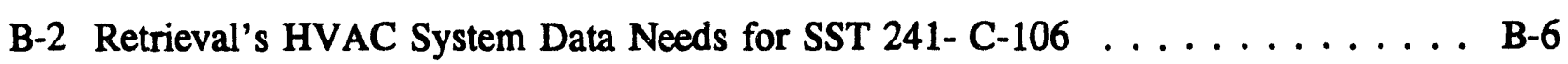




\section{LIST OF ACRONYMS AND ABBREVIATIONS}

$\begin{array}{ll}\text { cm } & \text { Centimeter } \\ \text { DOE } & \text { U.S. Department of Energy } \\ \text { DOE-HQ } & \text { U.S. Department of Energy, Headquarters } \\ \text { DQO } & \text { Data Quality Objective } \\ \text { DREAM } & \text { Data Requirements, Evaluation, and Management Project } \\ \text { DST } & \text { Double-Shell Tank } \\ \text { EPA } & \text { U.S. Environmental Protection Agency } \\ \text { FY } & \text { Fiscal Year } \\ \text { GC/MS } & \text { Gas Chromatography/Mass Spectroscopy } \\ \text { HEPA } & \text { High-Efficiency Particulate Air Filter } \\ \text { HLW } & \text { High-Level Waste } \\ \text { HVAC } & \text { Heating, Ventilation, and Air Conditioning } \\ \text { HWVP } & \text { Hanford Waste Vitrification Plant } \\ \text { ICP } & \text { Inductively Coupled Plasma } \\ \text { MACTEC } & \text { A DOE Consulting Organization } \\ \text { MS } & \text { Mass Spectrometer } \\ \text { PNL } & \text { Pacific Northwest Laboratory } \\ \text { Pretreatment } & \text { Waste Pretreatment Program Element } \\ \text { QA } & \text { Quality Assurance } \\ \text { RSD } & \text { Relative Standard Deviation } \\ \text { Retrieval } & \text { SST Retrieval Project } \\ \text { SAP } & \text { Sampling and Analysis Plan } \\ \text { SAR } & \text { Safety Analysis Report } \\ \text { Sr } & \text { Strontium } \\ \text { SST } & \text { Single-Shell Tank } \\ \text { TCP } & \text { Tank Characterization Plan } \\ \text { TPA } & \text { Tri-Party Agreement } \\ \text { TWCP } & \text { Tank Waste Characterization Plan } \\ \text { TWRS } & \text { Tank Waste Remediation System } \\ \text { WHC } & \text { Westinghouse Hanford Company } \\ \text { WTS } & \text { Waste Tank Safety PA-3 } \\ \text { WTSP } & \text { Waste Tank Safety Program } \\ & \end{array}$




\subsection{INTRODUCTION}

This report was provided through a joint effort by the staff of Pacific Northwest Laboratory (PNL) and Westinghouse Hanford Company (WHC). Although the sampling data needs for high-heat tank 241-C-106 were evaluated before this Data Quality Objective (DQO) study began, the DQO process identified in this report has been used to confirm the data needs of the WHC Waste Tank Safety Program (WTSP) and the Single-Shell Tank (SST) Retrieval Project (Retrieval).

In order to meet tank 241-C-106 related milestones, [generated by DOE Safety Initiatives and Tri-Party Agreement (TPA)], the system designs for the high-heat safety contingency plan (Wang, 1993) and waste retrieval have already begun using conservative assumptions. The conservative system designs are based on past successful practice sluicing and best engineering judgment. The waste sampling and analysis activity for 241-C-106 is to support and verify these designs. It is highly desirable to obtain these data at an early date. The original schedule for 241-C-106 core sampling was November 1992. Due to schedule delay, the sampling activity is now scheduled for March 1994.

An uncertainty study on sampling and data analysis error tolerances is addressed in Section 3.3. In the unlikely scenario that the sampling analyses invalidate some of the design parameters necessary design modifications or additions could be made at a later date. The physical limitation to take two core samples (because of riser availability) plays an important role in the uncertainty evaluation.

A comprehensive sampling and analysis plan (SAP) for 241-C-106 that meets the needs of WTSP and Retrieval has been developed and is presented in Chapter 5.0. This Sampling and Analysis Plan provides a summary of the instructions to the hot cell and laboratory regarding the sample allocation and analyses of core material from tank 241-C-106. The contract for analytical work between the Tank Waste Remediation System (TWRS) Information Management Systems organization and the performing laboratory will be part of the Tank Characterization Plan (TCP) for 241-C-106.

\subsection{PURPOSE}

The purpose of this report is to document the results of two DQO efforts focused on tank 241-C-106. The DQO results will lead to a revised SAP for tank 241-C-106. Therefore, this report shall serve as the basis for the 241-C-106 Tank Characterization Plan, as described in the TPA Final Draft Milestone M-44-02 of the Hanford Federal Facility Agreement and Consent Order (Tri-Party Agreement). The Tank Characterization Plan will 
allow tank core sampling and characterization to resume as soon as possible while documenting that the data needs specified in this document were obtained through a formal DQO process. More background information regarding the DQO process is summarized in Section 1.3.

\subsection{SCOPE}

The revised SAP described in Section 5.0 is limited in scope to the next two core samples that will be obtained from tank 241-C-106. Two efforts were conducted through this DQO study. One effort that identified the needs of the WTSP was performed by Mr. Stan Blacker, Dr. Dan Goodman, and representatives of the WTSP. The documentation of that effort is presented as Appendix A. The second effort was conducted under the Data Requirements, Evaluation, and Management (DREAM) Project, which further identified the characterization needs of WTSP and Retrieval.

Chapter 2.0 provides background information on tank $241-\mathrm{C}-106$ and the DQO process. The chapters that follow provide overviews of the stakeholders' data needs. These needs are integrated into an optimized sampling and analysis plan. Appendices A and B serve mainly as documentation of the DQO process.

\subsection{DATA QUALITY OBJECTIVES BACKGROUND}

The DQO process is a tool developed by EPAs Quality Assurance Management Group and Superfund staff to support Total Quality principles. The DQO process is a 7-step process that creates qualitative and quantitative statements that specify the type of data required to support decisions that address problems associated with remedial actions.

Advantages to the use of the DQO process include focused data collection and reduced resource (time and money) expenditures (Rythum and Neptune 1991). The DQO process has 7 key steps which are as follows:

1. Understanding the context

2. Converging on a statement of the relevant questions

3. Defining the array of possible useful answers

4. Selecting the measures that will estimate the answers

5. Setting the error tolerances for the estimates

6. Arriving at a decision rule

7. Optimizing the design.

The goal of the DQO process is to focus data collection and characterization activities on what is needed, thus providing a technical product. The DQO process formally requires defined qualitative and quantitative statements that focus collection activities. The DQO process also includes a stopping rule so collectors know when enough data has been gathered 
to support decision-making. For tank 241-C-106, only two rotary-mode core samples are planned because of limited available raisers. The principles of DQO processes were followed to the limit based on this physical limitation. 
This page intentionally left blank. 


\subsection{BACKGROUND ON 241-C-106 CORE SAMPLING DQO}

\subsection{BACKGROUND}

This report documents the results of a DQO study that was performed for tank 241-C-106 safety issue resolution and waste retrieval. The DQO process optimizes sampling and analytical requirements for a given system or issue by linking the requirements to key question(s) required for issue resolution.

The original objectives of this study were to:

- Evaluate the DQO process for a Hanford Site TWRS issue or waste tank

- Train project managers in the application of the DQO process

- Serve as site-wide training in the application of the DQO process for a set of Hanford Site DQO specialists who could then use the DQO principles to address other TWRS issues, and thus form a basis for tank characterization strategies

- Finalize plans for the resolution of tank 241-C-106 characterization issues

- Apply the DQO process to meet the needs of WTSP, Retrieval, and other TWRS program elements [such as Pretreatment, Hanford Waste Vitrification Plant (HWVP), and Grout projects] found to have legitimate characterization needs with respect to $241-\mathrm{C}-106$

- Document lessons learned during the study.

The results of this 7-step DQO process have been useful in the development of a revised sampling and analysis plan which replaces the analyses identified for tank 241-C-106 in the Tank Waste Characterization Plan (TWCP) (Bell 1993). This report provides a summary discussion of the DQO process used to develop the new plan. A subsequent report of lessons learned during the study was issued in August 1993 (Peffers et al., 1993). It contains a more comprehensive discussion of the DQO process regarding tank 241-C-106.

High heat generation in tank 241-C-106 requires the addition of water along with forced ventilation to mitigate potential structural problems caused by the high temperatures if not mitigated. This tank is also the first SST scheduled for retrieval in fiscal year (FY) 1997.

Before the initiation of this study, many TWRS elements had focused on tank 241-C-106. Its status as a high-heat and early-retrieval tank made it a high priority tank for WTSP. Early estimates of 241-C-106 waste composition resulted in plans for early retrieval, pretreatment, vitrification, and grout. However, the level of planning for these activities varied with each group. Consequently, the ability to define the type, quality, and quantity of the data needed 
to support the program as a whole (and its functional elements) was extremely variable. For example, WTSP had a good initial definition of its decision logic for the issues and data requirements relevant to 241-C-106. This allowed for completion of the DQO process in the safety area by February 1993. The data needs of the other program elements were more difficult to define because of the developmental statuses and uncertainties of the program elements. As a result, a decision was made in October 1993 to focus attention on the sampling and analysis needs for only WTSP and Retrieval.

Training was provided to prospective DQO specialists and other key participants, through several classes conducted by Mr. Stan Blacker and Dr. Daniel Goodman, who are originators of the DQO method. Further experience was gained through application of the DQO process to tank 241-C-106.

This DQO study began in August 1992 by a U.S. Department of Energy (DOE) consulting organization, MACTEC, to focus data collection for the next core sampling event. The objective of this study was to collect needed information to support TWRS decisions specific to the effective remediation of tank 241-C-106.

The DREAM project was established at the beginning of fiscal year 1993 to provide a permanent organization for implementing DQO efforts at the Hanford Site. To more effectively complete this task, 5 TWRS functional data user groups were created. These groups included representatives from operations, planning, safety, design, and analytical organizations. These groups met to execute the 7-step DQO process. In its most fundamental terms, the DQO process focuses on answering the following questions: (1) What do you need to know?; (2) Why do you need to know it?; and (3) How good, in a quantitative sense, must the data be to make the decision at hand? The "lessons learned" report discusses the process in more detail as it applied to 241-C-106 (Peffers et al., 1993).

As mentioned above, because of significant uncertainties and project cancellation, the original scope to cover the initial 5 functions (safety program, retrieval, pretreatment, HWVP, and Grout) was reduced to 2 functions (safety program and retrieval). The end result of this study, therefore, focuses only on the data needs for WTSP and Retrieval. The best-estimate schedule for rotary core drilling in tank 241-C-106 is March 1994. Sample analysis will follow at the PNL laboratory, assisted by the WHC laboratory.

\subsection{TANK 241-C-106 DQO ASSUMPTIONS}

Tank 241-C-106 is one of 149 SSTs at the Hanford Site that present waste disposal issues being addressed by TWRS. For this study several key assumptions were identified that relate 
to planning for the next 241-C-106 core sampling events and characterization efforts. These assumptions are as follows:

- Resolution of the high-heat safety issue is the highest priority for tank 241-C-106

- Two full-length sample cores will be taken in FY 1994

- Tank 241-C-106 will be retrieved in FY 1997. 
This page intentionally left blank. 


\subsection{PROGRAM DATA NEEDS}

To support the scheduled sampling and analysis for 241-C-106 in FY-1994, only inputs and needs from WTSP and Retrieval are considered for this DQO study. Other programs (pretreatment, grout and vitrification) are either not fully developed or canceled at this time. Their requirements will be addressed in the future as part of the Double Shell Tanks (DST) programs.

\subsection{FUNCTIONAL AREA DATA NEEDS}

This section includes a discussion for WTSP and Retrieval. The 241-C-106 characterization needs, the timing for those needs, the programmatic maturity of relevant issues, and the type of data required are addressed for each element. The DQO process and data needs for WTSP are documented in Appendix A. Detailed data needs for Retrieval are listed in Appendix B. A more detailed discussion of the DQO steps (expanded context, question development, etc.) supporting Appendix B are included in a "lessons learned" report (Peffers, et al., 1993).

\subsubsection{Waste Tank Safety Program}

Because tank 241-C-106 is a heat-generating tank requiring the regular addition of cooling water, WTSP :nonitors the tank closely. Between 1969 and 1971, strontium (Sr)-rich solids, the principal source of heat, were inadvertently transferred to tank $241-\mathrm{C}-106$. The ${ }^{90} \mathrm{Sr}$ is thought ts be distributed throughout all but the original hard layer in the bottom of the 241-C-106 tank. The continual generation of heat, if not mitigated, could compromise the integrity of the tank and increase the risk of a tank waste release. In FY-1997, the tank waste is scheduled to be removed to a double-shell tank (DST) designed to store high-heat waste.

The time required to resolve the safety issue is a major concern for characterizing tank 241-C-106. There are several TPA and Safety Initiative schedule commitments, including TPA milestones M-45-01 (for retrieval in FY 1997) and M-40-05 (which requires minimum cooling and water addition by September 1995). Core sampling 241-C-106 is the critical path activity in support of these milestones. The resolution of this safety issue has been given the highest level of TWRS characterization priority.

The WTSP organization has focused on resolving the high-heat problem for some time and therefore has a well-defined understanding of safety-related decisions and their dependence on data. WTSP also has a good database from which to work, given available historical data on temperature profiles of this tank, past-practice documentation, and analytical results. 
On the basis of prior analysis, the DQO process determined that key data were needed during the next sampling event; to 1) confirm the ${ }^{90} \mathrm{Sr}$ concentration distributions; 2) determine the thermal conductivity of the wet and dry waste; and 3) evaluate the permeability of the waste -- the ability of the waste to take up water after it has been thoroughly dried. This information will be used to verify alternative contingency actions should a tank leak develop and because of related safety systems designs. The DQO process confirmed the key data requirements previously identified by WTSP.

\subsubsection{Retrieval}

Because of past-practice experience, retrieval has a clear knowledge of the methods of sluicing. The reference retrieval option for 241-C-106 is sluicing, with a backup option of using remote sludge mobilization and retrieval tools delivered by a long-reach arm. While sluicing designs have been shown to be effective, current regulations and required probabilities of operational success require that this sluicing system not be designed and permitted for operation without supporting data. Sluicing pump power can be limited by the size of the tank access risers. Similarly, the number or position of risers limits the number of sluicing systems that can be delivered.

The new Tri-Party Agreement Final Draft Milestone M-48-01 requires development of SST retrieval technology. Tank $241-\mathrm{C}-106$ has been chosen for this demonstration. Delays in sampling of 241-C-106 in FY 93 and the consequential lack of important characterization data forced Retrieval to rely on historical information for design purposes. However, historical data, while available, are inadequate to ensure successful retrieval demonstration and satisfy regulatory permitting requirements no matter how conservatively the data are applied. Retrieval needs rheological, physical, and corrosivity data to confirm the design of a sluicing system ensuring safe and effective sluicing operations.

Tank 241-C-106 has a surface crust and hard bottom layer. The preliminary design is based on the assumption that sluicing will be effective in removing the surface crust, but will be unable to effectively remove the bottom hard-pan layer. If at least one core can be obtained in the rotary mode, physical and rheological information will be obtained to support design of the Long Reach Manipulator Project that will remove the hard pan waste following sluicing. At this time, two rotary-mode cores are scheduled for March 1994.

Confirmation on the hardness and rheological properties of the crust and sublayers was defined as high priority data during the DQO process. Retrieval also needs other data to ensure regulatory compliance. Additional data on abrasiveness and radionuclide concentrations will be used to support system design, material selection, and operations. Flexibility exists in the sluicing design, but risks and costs associated with system failures or inadequacies require additional data to diminish concerns to an acceptable level.

Furthermore, temperature readings at different thermocouples suggest that there is horizontal as well as vertical inhomogeneity in tank 241-C-106. For this reason, it is important that the requested characterization data be obtained from both sampling locations. 
The definitive retrieval systems design already began in August 1993, based on conservative assumptions to support M-07-00 milestone. The bounding and characterization data to support retrieval system design is not yet available. This data is needed as soon as possible.

\subsubsection{Other User Groups}

While WTSP and Retrieval data user groups have defined data needs, other program elements will benefit from the data collected from 241-C-106. For example, the TWRS Information Management Systems organization gains knowledge about spatial variability and analytical variability associated with rheological data. This data was not captured in the analyses of tanks 241-B-110 and 241-U-110. The sampling of these tanks was designed to clarify the nature of variability of materials within High-Level Waste (HLW) tanks. The main emphasis of the DQO process is to ensure that the essential data user groups get timely and sufficient data to accomplish their goals. However, the process should allow for the beneficial use of the data by all users.

\subsection{SUMMARY OF DATA NEEDS}

The data users mentioned above all have data needs that should be tied to their respective programs and should support process development decisions. All decisions require information immediately. WTSP and Retrieval require sampling data as soon as possible to verify ongoing system designs that already started to meet specific TPA and Safety Initiative milestones. This DQO pilot study focuses on the data needed in WTSP and Retrieval.

\subsection{DECISION RULES AND ERROR TOLERANCES}

Defining decision rules and arriving at acceptable error tolerances is often an iterative process. This process is entirely dependent on the sampling objectives, assumptions, and questions defined in the first few steps of the DQO process. This section summarizes the development of decision rules, error tolerances, and statistical designs that were encountered and applied to Retrieval and the High Heat Safety Program. Because of the very conservative safety margin built in the analyses and design, and the accommodations for design modification and operational flexibility, the error tolerances for Retrieval and Safety Program data do not require a very tight interval. No consequence concerning public and workers safety is expected as a result of larger-than-expected data errors. 


\subsubsection{Underlying Assumptions}

On the basis of discussions with the Retrieval and Safety Program staff, the following assumptions were imposed before developing a statistically optimal sampling and analysis plan for the 241-C-106 campaign:

- Two core samples will be obtained from 241-C-106.

- Normal distribution theory will be applied.

- WTSP is primarily concerned about thermal responses in abnormal tank conditions, such as leaking or loss of ventilation. The data needs for the WTSP is to confirm the conservative assumptions used for the thermal analyses.

- Retrieval is primarily interested in the properties of the top (crust) and bottom (sludge) segments for each core. They are also primarily concerned with bounding conditions.

\subsubsection{Error Tolerances}

In the traditional DQO process, a rigorous statistical approach is applied to determine the required number of samples. This will ensure that incorrect decisions be held to an acceptable level. To proceed through the statistical approach, previous estimates of spatial, sampling, and analytical uncertainty must be available. Because no previous reliable estimates of uncertainty (particularly spatial variability) for the key measures of interest (rheology, physical, corrosivity, thermal conductivity) are available from this or similar tank historical records or samples, the statistical components in the last two steps of the DQO process could not be completed without significant, unsubstantiated assumptions. It should be noted that bulk density measurements were available from B-110 core samples and that spatial, sampling, and analytical variability exhibited is not necessarily a reliable estimate of the variability for other measures of interest. Therefore, in this section, somewhat hypothetical attainable decision error levels are discussed given the determination that only two samples will be obtained.

For retrieval data needs, the extreme values for the measures of interest may be more important than the average values. Therefore, after the data are gathered, one may be interested in computing a statistical tolerance interval rather than a confidence interval. A tolerance interval is a statement about the population range whereas a confidence interval is a statement about the mean of the population. For example, a tolerance statement would be "one can be X\% confident that at least $\mathrm{Y} \%$ of the population lies within the interval" whereas a confidence statement is "one can be $\mathrm{X} \%$ confident that the true mean value lies within the interval."

If previous estimates of variability were available, one could determine the number of samples required to achieve an acceptable probability of making incorrect decisions based on 
the data. This may be in the form of determining an acceptable tolerance interval width. Alternatively, because the number of samples to be obtained is 2 , one could deternine the expected tolerance interval width and determine whether it is acceptable. To illustrate, suppose we consider density and use estimates of uncertainty from the B-110 tank core samples. Assume that a tolerance interval is desired for the top segment (crust) only. The B-110 estimate of relative standard deviation (RSD) including horizontal spatial, sampling, and analytical uncertainties for bulk density is $0.01385(1.4 \%)$. Using statistical tolerance tables to derive the appropriate multiplication factors, one can be $90 \%$ confident that at least $90 \%$ of the population will be within $\pm 0.01385 * 16=0.2215$. Thus, if 2 samples are obtained and the RSD is $1.4 \%$, the width of a $90 \% / 90 \%$ tolerance interval is expected to be $\pm 22 \%$ of the sample mean.

It is important to note that for density this expected tolerance interval width may be acceptable but a different width would be expected for each of the measures of interest. Therefore, an assessment of the adequacy of 2 cores from C-106 cannot be accomplished at this time. However, based on the fact that the consequences of decision errors appear to be minimal (may result in minor delays and no safety consequences due to operational monitoring plans), it is expected that two samples would be sufficient to control the probability of decision errors to acceptable levels.

By making reasonable assumptions concerning variations and statistical distributions coupled with the information on thermal conductivity presented above, one can illustrate the determination of attainable statistical confidences that the true mean thermal conductivity is greater than $0.25 \mathrm{Btu} / \mathrm{hr}-\mathrm{ft}-\mathrm{F}$. Suppose one is interested in knowing how confident one is that the true mean thermal conductivity is greater than $0.25 \mathrm{Btu} / \mathrm{hr}-\mathrm{ft}-\mathrm{F}$ given the results after sampling from C-106. As indicated previously, the range of the error tolerance evaluation for Retrieval is also applicable to the WASP data requirement. A number of thermal analyses using very conservative assumptions based on available information and engineering judgment, were performed in the past for the High-Heat Safety Program. The most important input for the analyses is the estimated thermal conductivity of the waste. A bounding value of $0.25 \mathrm{Btu} / \mathrm{hr}-\mathrm{ft}-{ }^{\circ} \mathrm{F}$ has been used for the analyses. For some of the key thermal analyses, even $0.10 \mathrm{Btu} / \mathrm{hr}-\mathrm{ft}-{ }^{\circ} \mathrm{F}$ was used for sensitivity studies. The known thermal conductivities for the waste are between 0.25 to $0.50 \mathrm{Btu} / \mathrm{hr}-\mathrm{ft}-{ }^{\circ} \mathrm{F}$. The attainable levels of confidence based on two core samples can be accomplished by making reasonable assumptions concerning variations and statistical distributions, and then calculating lower confidence limits for various possible measured mean values.

This is illustrated for the thermal conductivity measurement. As indicated previously, the range of thermal conductivity measurement is estimated between 0.25 and $0.50 \mathrm{Btu} / \mathrm{hr}-\mathrm{ft}-{ }^{\circ} \mathrm{F}$. If one could assume that the values were normally distributed over this range with a mean of 0.375 and this range contained $95 \%$ of the possible values, a priori estimate of the standard deviation can be obtained. This estimate is required to develop any confidence statements. When measurements are obtained from the two core samples, the mean and standard deviations will be calculated and based on distributional assumptions a lower confidence limit will be calculated and compared against the lower threshold ( 0.25 in this case). Suppose the 
measured mean value is 0.30 and the relative standard deviation is $16 \%$ of 0.375 . One may want to know whether the true mean value is $>0.25$. This is shown in Table 3-1 (e.g., if the mean result from sampling were 0.30 and the relative standard deviation were $16 \%$ of 0.375 , then one can be $77 \%$ confident that the true mean is $>0.25$ ).

Table 3-1 shows the attainable statistical confidences for various measured mean values and several assumed relative standard deviations (relative to 0.375 ). The table can also be used in a generic sense by using the percent difference from the lower threshold and some assumed relative standard deviation.

Table 3-1. Confidence Statements for Thermal Conductivity Mean.

\begin{tabular}{|c|c|c|c|c|c|}
\hline $\begin{array}{c}\text { Measured } \\
\text { Value }\end{array}$ & $\begin{array}{c}\% \\
\text { Difference }\end{array}$ & RSD = 16.7\% & RSD = 10\% & RSD = 25\% & RSD = 50\% \\
\hline 0.25 & $0 \%$ & $50 \%$ & $50 \%$ & $50 \%$ & $50 \%$ \\
\hline 0.30 & $20 \%$ & $77 \%$ & $84 \%$ & $71 \%$ & $61 \%$ \\
\hline 0.35 & $40 \%$ & $87 \%$ & $92 \%$ & $81 \%$ & $71 \%$ \\
\hline 0.40 & $60 \%$ & $91 \%$ & $94 \%$ & $87 \%$ & $77 \%$ \\
\hline 0.45 & $80 \%$ & $93 \%$ & $96 \%$ & $90 \%$ & $81 \%$ \\
\hline 0.50 & $100 \%$ & $94 \%$ & $97 \%$ & $92 \%$ & $84 \%$ \\
\hline
\end{tabular}

More discussions on error tolerances and decision rules are documented in A5.0 and A6.0 of Appendix A. This error tolerance section is provided to illustrate how one might approach the evaluation of whether 2 core samples will provide adequate protection against making incorrect decisions if estimates of spatial, sampling, and analytical variations were available. Because no previous estimates of variations are available for the key measurements of interest, a statistically rigorous evaluation is not feasible at this time.

It is recommended that the sampling and analytical approach require analyses for key measurements of interest be performed on duplicate samples from each segment sampled including the top and bottom segments. This will allow for the estimation and detectability of spatial, sampling, and analytical uncertainties once the data have been obtained. 


\subsection{SUMMARY OF RESULTS FOR TANK 241-C-106}

\subsection{RESULTS}

This DQO study provides a basis of data needs for the sampling and analysis of waste from tank 241-C-106. This sampling and analysis is required to support the near-term data requirements for TWRS program elements. The main objective of this 241-C-106 DQO pilot study is to identify the data needs for WTSP and Retrieval. The activities that result from this study are as follows:

- Thermal conductivity measurements (wet and dry) will be performed to support resolution of the high-heat safety issue.

- To support the development of a more accurate thermal model of the tank waste, the vertical distribution of heat-producing ${ }^{90} \mathrm{Sr}$ will be identified using a beta scan of the extruded core segment. If a beta scan is not possible or available, analysis for ${ }^{90} \mathrm{Sr}$ will be performed on each segment.

- Rheological data and other physical/chemical characterization will be obtained to support retrieval design and regulatory compliance.

- A revised sampling and analysis plan will be developed that incorporates the decision-based characterization requirements of Safety and Retrieval.

The WTSP is primarily concerned about obtaining data on ${ }^{90} \mathrm{Sr}$ layering, thermal conductivity, and permeability. Justifications for these data requirements include the assurance that retrieval of any given amount of waste can be checked to determine if the high-heat safety issue is resolved, and that the system designs for a contingency action plan are adequate in case of leaking. If $\mathrm{Sr}$ and thermal conductivity values are not known, there is a risk that the amount of waste remaining after retrieval may generate enough heat to pose a safety concern requiring modification of the contingency actions and/or related system design.

There is evidence from 241-C-106 historical data and thermocouple readings that the tank waste is both horizontally and vertically heterogeneous. Because the engineering design portion of Retrieval and contingency systems is more interested in understanding bounding conditions than averages, characterization results from more than one core is required to support engineering judgments related to sluicing pumps and piping designs. Two cores would provide the minimum data needed to better estimate/bound rheological/chemical uncertainties.

The contents of the waste tank, once retrieved, will be significantly more homogeneous and will probably be mixed with the contents of a holding tank. Consequently, the other program elements, as well as the Heating, Ventilation, and Air Conditioning (HVAC) sub- 
element of retrieval, need only the average composition of the tank. Analytic results from tanks 241-B-110 and 241-U-110 indicate that compositing gives the best estimates of averaging from a heterogenous tank; thus, at least two cores need to be obtained. Therefore, a minimum of two cores are recommended for tank 241-C-106. An uncertainty study based on two cores is summarized in Section 3.3.

\subsection{IMPLEMENTING RESULTS}

Regardless of the start date for coring 241-C-106, the results from this DQO study can be incorporated into the analytical procedures for the next tank corings. This report provides guidance for the preparation of a TCP specific to tank 241-C-106 instructing the laboratory on what analyses to perform. The sampling events should be scheduled as soon as possible to minimize the impact on the 241-C-106 retrieval and contingency plan system design schedules. 


\subsection{TANK 241-C-106 REVISED SAMPLING AND ANALYSIS PLAN}

\subsection{INTRODUCTION}

The summary of the revised sampling and analysis plan that is presented below for the characterization of tank 241-C-106 will be used to prepare a specific Tank Characterization Plan (TCP) for that tank. This section describes the sample allocation and analytical requirements to adequately characterize $241-\mathrm{C}-106$.

\subsubsection{Requirements, Procedures, and Definitions}

The revised sampling and analysis plan serves to indicate the appropriate waste sample allocations and analyses performed on wastes from two cores of tank 241-C-106, as identified through a formalized DQO process. Since the contract for analytical work between the TWRS Information Management Systems organization and the performing laboratory will be in the 241-C-106 TCP, all requirements, procedures, and definitions not described here will be delineated in the TCP or the FY 1994 Tank Waste Analysis Plan.

\subsection{CORE SAMPLE ANALYSES}

The 241-C-106 DQO study has identified the needs for the TWRS program element of Retrieval. However, the needs for WTSP were addressed in a separate DQO effort. The results from that DQO effor show that the requirements for WTSP may be met with 1) a quarter segment-level analysis of ${ }^{90} \mathrm{Sr}$; 2) thermal conductivity on wet and dry unhomogenized stratum material; and 3) a measure of waste permeability. Statistical analyses indicate that this information should be obtained from at least two core samples. The needs of Retrieval will also require analyzing at least two cores to obtain information on bounding conditions.

\subsubsection{Analysis Definitions}

The definition or clarification of terms, analyses, or measurements found in this revised sampling and analysis plan are listed below.

- Lithium may be used as a hydrostatic head fluid tracer if push-mode sampling is used (rotary-mode is being planned) and may be analyzed by atomic absorption or ICP. This method will be specified in the 241-C-106 TCP. 
- Permeability measurements determine the ability of the waste material to absorb water after it has been dried. The TWRS Information Management Systems organization will communicate with the performing laboratory to define a procedure for this measurement.

- Thermal Conductivity measurements are to be made on both as-sampled wet solids and waste that has been thoroughly dried at $104^{\circ} \mathrm{C}$.

\subsubsection{Core Sample Analysis}

A flowchart depicting the sampling and analysis scheme for both cores is presented below as Figure 5-1. Each step in the flowchart is described in detail.

Tank Farm Operations will obtain the core samples from tank 241-C-106. As a minimum, rheological and selected physical properties are to be made on the first and last full segments of both cores. Rheological measurements will also be performed on other segment material (as usual) if a unique stratum is identified in the remaining segments of either core, and provided there is adequate material available. Personnel from Retrieval shall be invited by TWRS Information Management Systems to witness the segment extrusions of all segments. Retrieval will help designate portions of the segments for rheological testing. It is imperative that all rheological measurements for each segment are performed using the same set of $1: 1$, 3:1, and 5:1 dilutions at ambient temperature and $95^{\circ} \mathrm{C}$. All unhomogenized sample material from tank 241-C-106 remaining after all other characterization samples have been taken shall be archived and retained for future physical properties measurements until sluicing operations are completed in tank 241-C-106.

- Step 1. Core samples will be transported to and received at the laboratory in accordance with approved procedures.

- Step 2. Samples will be extruded and broken down at the laboratory using approved procedures. Visual observations to be recorded for each segment include a sketch of the extruded segment and include such pertinent, and descriptive information as color, texture, homogeneity, and consistency. The color and clarity of any drainable liquid will also be noted. Physical parameters to be recorded include the volume and weight of the segment, the bulk density, the percentage of the expected sample that was recovered, length of the segment, volume of drainable liquid, and volume of any liquid in the liner. A video recording of the extrusion documenting the extruded segment shall also be made.

- Step 3. The drainable liquid is separated from the solids by allowing the liquid to drain into a clean bottle. The extruded solids are to be retained in the extrusion tray for further subsampling and analyses (described below).

- Step 4A. Determine the volume, weight, and density of the liquid. 
- Step 4B. If the core sample was taken in the push mode, continue with Step 4C; otherwise go to Step 5.

- Step 4C. Perform analyses for $\mathrm{Li}^{+}$and $\mathrm{Br}$ on the drainable liquids in each segment.

- Step 5. If the segment is from the first segment in the core, continue to Step 7A; otherwise go to Step 6.

- Step 6. Determine whether the segment contains material from a new stratum. Physical and rheological measurements will be performed on material devoid of drainable liquid for each new strata in addition to the first and last segment in the core.

- Step 7A. Take representative samples from the segment for physical and rheological tests. There are two methods for sampling the segment, splitting the segment lengthwise, or taking random samples along the length of the segment. These methods are as follows:

- Split Sample. If possible, the segment should be split lengthwise while still in the extrusion tray. One portion of the split segment is reserved for the rheology/physical tests, and the other portion for the segment analyses. The portion designated for the segment analyses should be placed in a numbered and tared, capped jar for subsequent homogenization (Step 10). Material for the rheological/physical tests is placed in a second numbered and tared jar using care to disturb the sample as little as possible.

- Random Sample. If the waste material is not cohesive enough to split, then randomly remove to a numbered and tared jar $\sim 10-15 \mathrm{~g}$ of sample from every $10 \mathrm{~cm} \mathrm{(4} \mathrm{in.)} \mathrm{along} \mathrm{the} \mathrm{length} \mathrm{of} \mathrm{the} \mathrm{segment} \mathrm{in} \mathrm{order} \mathrm{to} \mathrm{obtain}$ material for the rheological/physical tests. The remaining material is placed in a second numbered and tared jar for the core composite.

- Step 7B. For both cores, perform analyses for rheology and physical tests as shown in Figure 5-2. The rheological properties should be measured at two temperatures, ambient and $95^{\circ} \mathrm{C}$, for the as-sampled aliquot and each 1:1, 3:1, and 5:1 dilution.

- Step 7C. Remove approximately $2 \mathrm{~g}$ of sample from every $4-5$ inches along the extruded segment for ${ }^{90} \mathrm{Sr}$ analysis. There shall be a total of four samples from each segment.

- Step 7D. Perform ${ }^{90} \mathrm{Sr}$ analyses on a fusion dissolution of the above samples.

- Step 8. If the segment is the last segment of the core, go to Step 9A; otherwise go to Step 10. 
- Step 9A. See Step 7A.

- Step 9B. See Step 7B.

- Step 9C. See Step 7C.

- Step 9D. See Step 7D.

- Step 9E. Separate any hardpan material from the remainder of the waste.

- Step 9F. Homogenize the waste types separately.

- Step 10. Homogenize the entire segment.

- Step 11. Perform segment-level analyses as specified in Figure 5-2.

- Step 12. If all segments have not been extruded, go to Step 2; otherwise, proceed to Step 13.

- Step 13A. Prepare a liquid composite for each core by combining portions of the drainable liquids from each segment. Identify and report all segments, volumes, and weights used to make the composite.

- Step 13B. Combine and homogenize portions of the wet solids from each segment of a core into a single core composite. Hardpan material shall be excluded. Identify and report all segments, volumes, and weights used to make the composite.

- Step 14A. Perform th a liquid composite analyses of both cores as specified in Figure 5-3.

- Step 14B. Perform the core hardpan composite analyses of both cores as specified in Figure 5-4. The homogenized hardpan material from Step 9F is designated as the hardpan composite.

- Step 15A. Retain the liquid composite from each core as the liquid composite archive sample.

- Step 15B. Retain the core and hardpan composite material from each core as the core composite sample archives. 
Figure 5-1. Cores 1 and 2, Test Plan Flowchart.

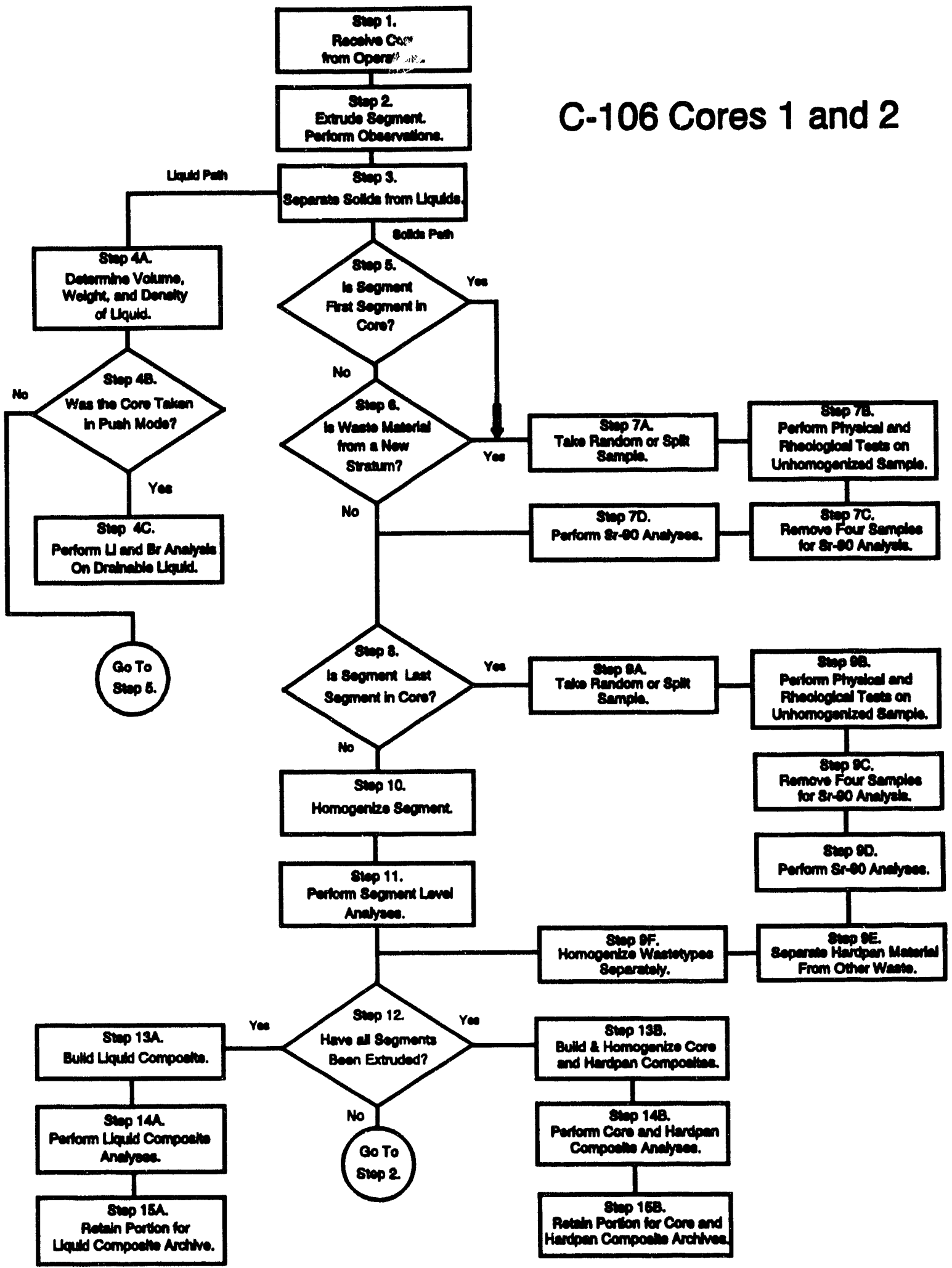


Figure 5-2. Cores 1 and 2, Physical and Segment-Level Analyses.

\section{C-106}

\section{Cores 1 and 2}

Unhomogenized

(Strata)

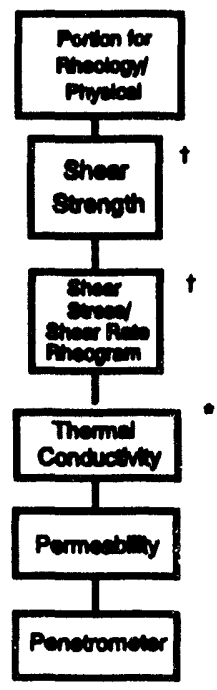

Homogenized

(Segment)

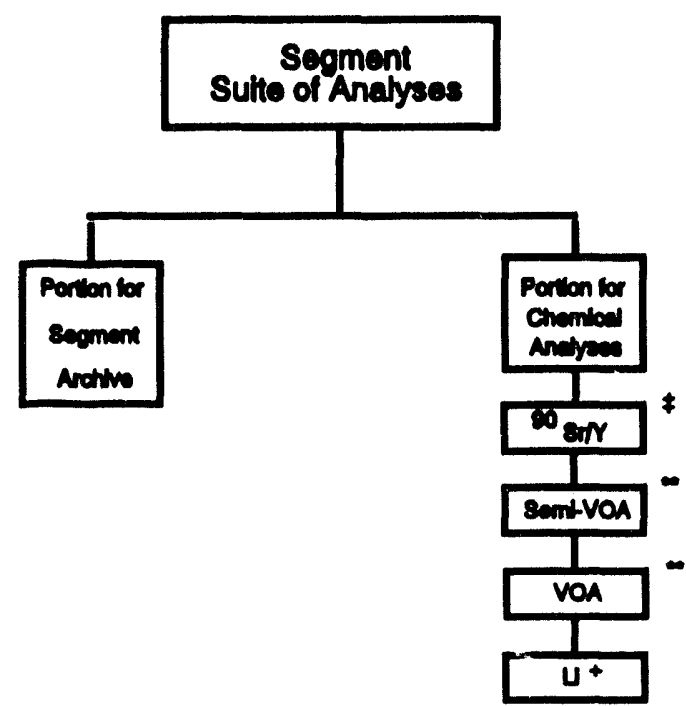

* This analyeis is performed on the quarter segment lovel on unhomogenlzed waste.

tThese enalyees are performed on sa-sampled waite and on $1: 1,3: 1$, and 5:1 dilutions at ambient and $05^{\circ} \mathrm{C}$ using $0.01 \mathrm{M}$ NaOH as diluent.

Measured on es-eampled and dited wasto.

- Samplo removed from unhomogenized wate Immediately following extrustion.

Homogenized

(Seoment)

-Homogenization test performed once per coro.

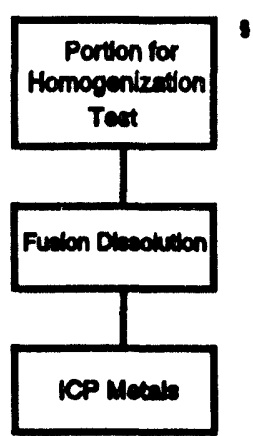


Figure 5-3. Cores 1 and 2, Liquid Composite Analyses.

C-106

Cores 1 and 2

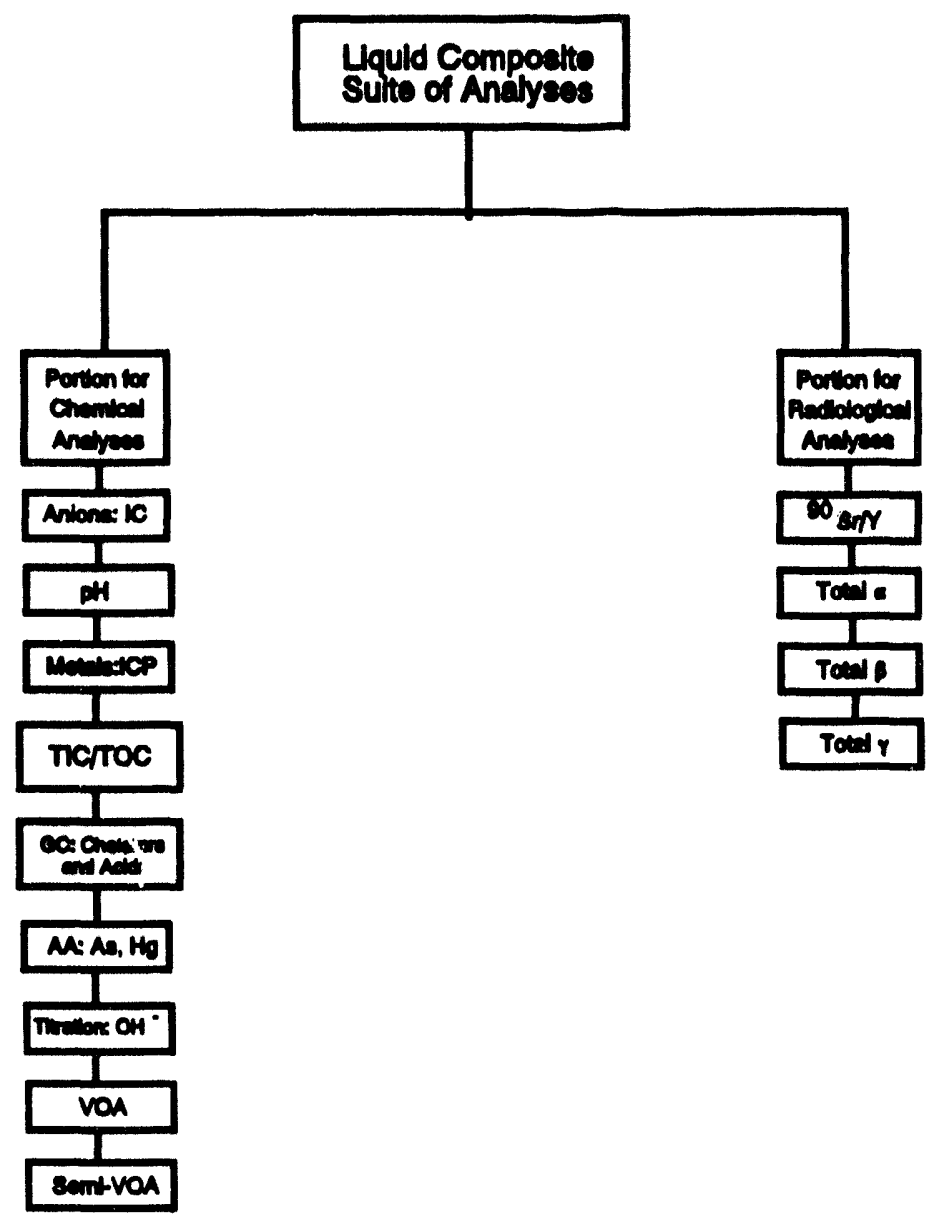


Figure 5-4. Cores 1 and 2, Core Composite Analyses.

\section{C-106 \\ Cores 1 and 2}

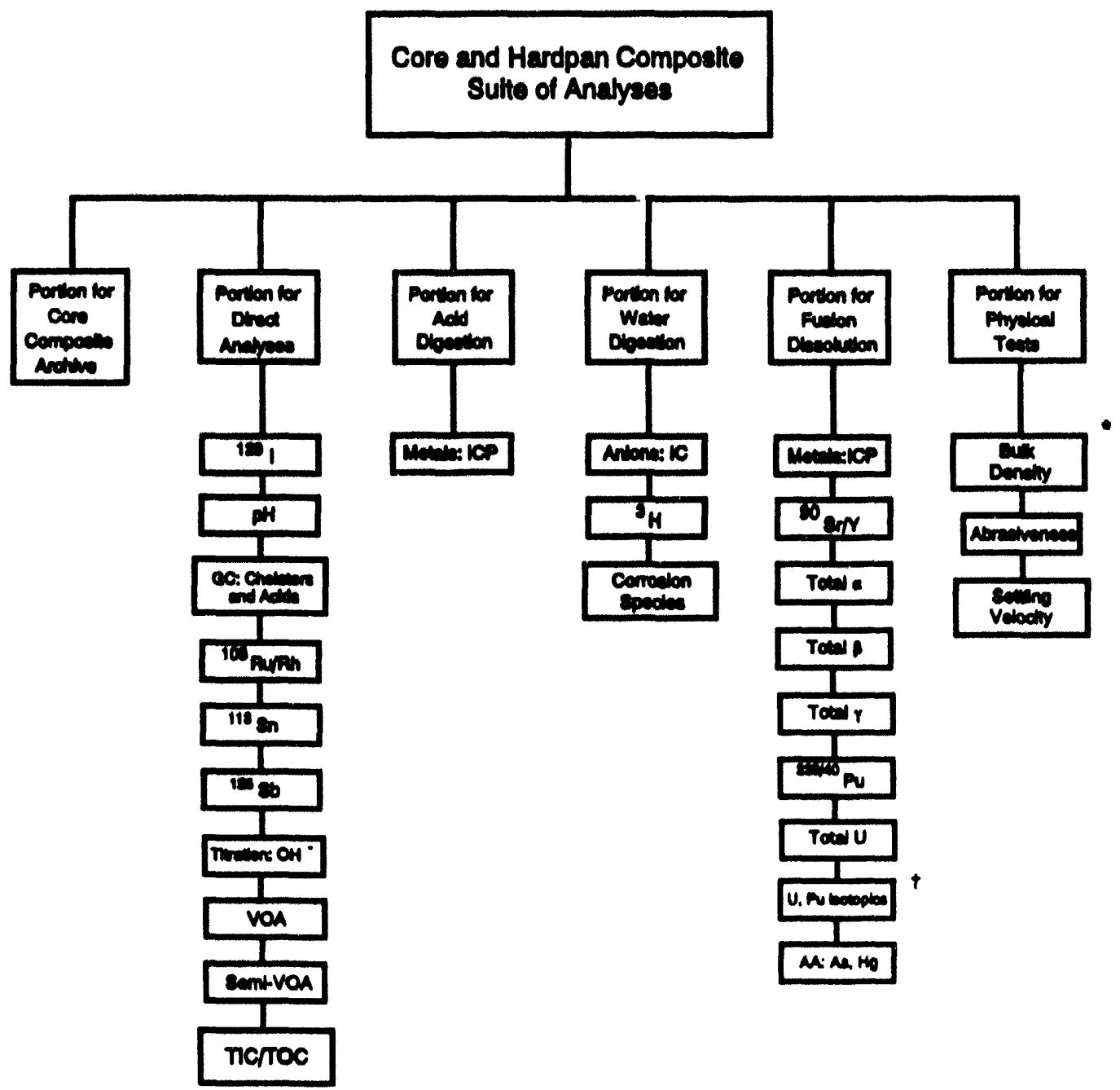

These analyess ane portormed on as-eanpled waste and on 1:1, 3:1, and 6:1 dllutions at ambient and 95० $C$ uaing $0.01 \mathrm{M} \mathrm{NaOH}$ es dlluem.

'U and Pu botoples pertormed only II total alpha > (total alpha-total U). 


\subsection{REFERENCES}

Bell, 1993, Tank Waste Remediation System Tank Waste Characterization Plan, WHC-SD-WM-PLN-047, Rev. 1, Westinghouse Hanford company, Richland, Washington.

EPA, Ecology, and DOE, 1993, Hanford Federal Facility Agreement and Consent Order (Tri Party Agreement), 2 vols., Washington, D.C.

Peffers, M. S., 1993, C-106 Data Quality Objective Study: Lessons Learned and Recommendations, letter report August 31, 1993, Pacific Northwest Laboratory, Richland, Washington.

Rythum, R. T. and D. Neptune, 1991, "Planning Issues for Superfund Site Remediation," Hazandous Material Control, 3 (3): 19-27.

Wang, O. S., 1993, "High Heat Safety Issue Resolution Program Plan", WHC-EP-0532, Rev. 1, Westinghouse Hanford Company, Richland, Washington. 
This page intentionally left blank. 


\section{APPENDIX A}

\section{INDEPENDENT WASTE TANK SAFETY PROGRAM DATA QUALITY OBJECTIVES EFFORT}


WHC-EP-0723

This page intentionally left blank. 


\section{DQO PLANNING PROCESS - SEVEN STEPS FOR TANK C-106 SAFETY ISSUES}

\section{A1.0 UNDERSTANDING THE CONTEXT}

Between 1967 and 1971 tank 241-C-106 received Plutonium Uranium Extraction Plant (PUREX) supernate and PUREX sludge wash solutions, which are thought to have been the source of high levels of $\mathrm{Sr}$ that remained in the sludge through several episodes of continued additions to the tank and decantations from the tank. In 1971, because of observed high temperatures attributed to the high Sr levels, active ventilation of the tank was initiated to promote evaporative cooling, and the addition of replacement water at intervals began. The hardpan layer in the bottom of the tank is thought to have originated from materials added earlier than the transfers responsible for the high Sr levels, and this layer is not thought to be contributing significantly to the heat generation. Because of the concem that temperatures might exceed the levels thought allowable from the standpoint of long-term structural deterioration of the concrete walls, water additions to tank 241-C-106 have continued.

In 1992, an electrical failure resulted in a 5-month shutdown of the active ventilation in tank 241-C-106, and water addition ceased for the interim. During this shutdown, the observed temperatures at the hottest thermocouple rose approximately linearly with time, from $161^{\circ}$ to $199^{\circ} \mathrm{F}$, and the liquid level rose about $3 / 4$ in., owing presumably to expansion of waste volume with temperature. When active ventilation resumed, the temperature dropped $10^{\circ} \mathrm{F}$ in the first two weeks, and returned to former values in 5 months.

Tank 241-C-106 is scheduled to be retrieved in FY 1997. It is expected that this operation will retrieve essentially all of the sludge material and part of the hardpan. Tank 241-C-106 is scheduled for core sampling in FY 1994 (delayed from November 1992).

The WTSP requests that specific information be obtained during the sampling of tank 241-C-106 in order to address concerns that are their responsibility. WTSP's concerns about tank 241-C-106 include only considerations of heat generation and the ongoing water additions that are intended to control temperatures. There are two potential scenarios of concern to the WTSP. These are as follows:

\section{(a) Partial (Aborted) Retrieval}

In the event that the planned retrieval operation in tank 241-C-106 must be terminated before all the sludge material is removed from the tank, WTSP wants to know whether the heat generation of the remaining sludge will be low enough so that water addition can be reduced or terminated. 


\section{(b) Detection of a Leak Prior to Retrieval}

In the event that leakage from tank $241-\mathrm{C}-106$ is detected before retrieval begins, the WTSP wants to know what water addition rates are absolutely necessary or what contingency safety systems are adequate to control temperature (as there is a strong desire not to add any liquids to a leaking tank).

There is a range of possible rates of water addition to tank 241-C-106. The range begins at the present periodic additions, which continuously maintain a liquid water layer above the sludge material, to total cessation of water additions. The latter would allow the tank eventually to evaporate dry. Intermediate management policies include intermittent water additions at intervals long enough to allow partial drying under intermittent active ventilation.

A heat balance study was completed to address water additions and contingency safety systems design (air-chiller and in-tank sprinkler). The study uses thermal data from the 1992 shutdown period. This heat balance study concluded that all the mitigating methods were functions of heat generation distribution and thermal conductivity.

\section{A2.0 CONVERGING ON A STATEMENT OF THE RELEVANT QUESTION}

Both scenarios of concern involve a question about the continued need for water additions to maintain acceptable temperatures. In scenario (a) this question arises in the context of a partial retrieval, and in scenario (b) this question arises in the context of a decision made before retrieval. Both scenarios, therefore, may be understood as elements of the core question:

"If the top X inches of sludge are retrieved from tank 241-C-106, how much, and what type of water addition is necessary to prevent the temperature from exceeding $\mathrm{Y}$ at the tank wall?"

In this formulation, scenario (b) corresponds to a value $X=0$. It is not clear at present what the correct value is for the critical temperature $Y$, but conservative estimates are available. The SST operating specification limit is $300^{\circ} \mathrm{F}$, which includes a $50^{\circ} \mathrm{F}$ safety margin relative to the Safety Analysis Report (SAR) limit of $350^{\circ} \mathrm{F}$. The SAR limit itself is based on considerations of long-term denaturing of concrete, which may be overly conservative in the context of a tank that is scheduled for retrieval in 1997, and which under scenario (b) is presumed to be leaking, so long-term deterioration of the concrete is of less concern.

\section{A3.0 DEFINING THE ARRAY OF POSSIBLE USEFUL ANSWERS}

The array of possible useful answers is captured in the following:

"At intervals of $\mathbf{Q}$ days, $\mathbf{R}$ amount of water must be added, and active ventilation must be switched on for $\mathbf{S}$ days." 
Depending on the values for $Q, R$, and $S$, this statement encompasses the present policy of continuous active ventilation and water additions frequent enough to maintain a permanent water layer. It also encompasses the opposite extreme policy of complete cessation of water addition and active ventilation. It covers a continuous spectrum of cycles of partial drying. From this statement, the answer will consist of the values for $Q, R$, and $S$. Any nonnegative values in the set where $S$ does not exceed $Q$, and where $R$ does not exceed the freeboard, are meaningful, but for practical purposes the answers may be quantified in units such as whole days and multiples of 1,000 gallons. The amount of equivalent heat removal can be translated to system capacity (such as an air-chiller) for design purpose.

\section{A4.0 SELECTING THE MEASURES THAT WILL ESTLMATE THE ANSWERS}

The logic for deciding how much water addition and ventilation will be adopted under scenario (a) or (b) is hierarchical.

- The first pass will be an inventory calculation of whether the heat generation exceeds $40,000 \mathrm{Btu} / \mathrm{hr}$. If it does not, the decision will be that water addition can cease.

- If the heat generation does exceed 40,000 Btu/hr, a more detailed assessment will be necessary to predict whether tank waste temperatures will exceed a predetermined safety limit under the various options of managing water addition, ventilation, and/or of installing contingency safety systems.

The more detailed assessment will be conducted by use of a model. The important inputs to this model will be layer-by-layer values for heat generating constituents (Sr in the case of tank 241-C-106) and the layer-by-layer thermal conductivities, wet and dry (where "dry" refers to the degree of drying that would occur as a result of temperature excursions in the intervals between water addition).

In other words, the measures that will estimate the answers are the layer-by-layer $\mathrm{Sr}$ values and layer-by-layer values for thermal conductivity and permeability, whereas the answers themselves will be the estimated values of $Q, R$, and S. A thermal analysis for 241-C-106 concluded that the estimated heat level is approximately $110,000 \mathrm{Btu} / \mathrm{hr}$. The property of waste permeability is to estimate "re-wet" capability of a dried waste layer.

\section{A5.0 SETTING THE ERROR TOLERANCES FOR THE ESTIMATES}

There are many sources of error that arise when estimating the required water addition schedule (as expressed by the values of $Q, R$, and $S$ ). The principal sources of error to consider are as follows: 
- Vertical interpolation erroi arising from the sample core material not being an accurate representation of the vertical profile of tank contents

- Horizonial sampling error arising from horizontal inhomogeneity in the tank, because of the limited number of cores taken

- Analytical error in the measurements of $\mathrm{Sr}$ and thermal conductivity made on sampled tank 241-C-106 material

- Error inherent in the model used to predict the variables that establish the water management strategy (i.e., $Q, R$, and $S$ ) from the input measures of layer by layer $\mathrm{Sr}$ and thermal conductivity.

This model involves a complicated set of calculations that relate Sr heat generation, thermal conductivity, wall temperatures, and rates of cooling of tank contents when water is added. At each step in the calculations, errors arise that need to be quantified. Establishing values for these errors and determining how they propagate in the model is a complicated effort that would require some time.

There is a simpler alternative for determining how good the $\mathrm{Sr}$ and thermal conductivity data need to be in order to establish the desired water management strategy. If initial errors in Q, $\mathbf{R}$, and $\mathbf{S}$ do not have serious consequences, then the need to measure accurately $\mathrm{Sr}$ and thermal conductivity is reduced.

For the tank 241-C-106 water management strategy, the detection and correction of initial errors in $\mathrm{Q}, \mathrm{R}$, and $\mathrm{S}$, can be accomplished by real time monitoring of the tank temperatures. In this fashion, if the temperature trajectory appears to be headed towards unacceptable temperatures, the working values of $Q, R$, and $S$ can be readjusted in the direction of more cooling until an acceptable temperature regime is achieved.

The experience of the 1992 shutdown demonstrated that resumption of active ventilation can rapidly reverse a temperature excursion as long as the sludge is wet. This experience enables the pursuit of the above adaptive approach to setting water management (i.e., the values of $Q, R$, and $S$ ). The decision rule in the next step is built on this adaptive strategy.

As a result of this tank 241-C-106 experience, exploration of water management regimes that allow partial or total sludge drying only requires limited prior characterization. This characterization need only demonstrate that water addition and active ventilation will be effective in reversing temperature excursions for varying degree of drying.

This adaptive approach reduces greatly the need for quantifying an acceptable error level in the model input (that is, the error in estimates of layer-by-layer Sr concentration and thermal conductivity). Starting with model-predicted values of $\mathbf{Q}, \mathbf{R}$, and $\mathbf{S}$ that need only be in the 
right "ball park," and following this adaptive strategy, convergence is obtained for the desired values of thermal conductivity. This will not have adverse consequences because of the ease in detecting and recovering from a temperature excursion.

Thus, the requested precision for measurements of Sr and thermal conductivity will be easily achieved with simple and inexpensive laboratory analytical procedures.

\section{A6.0 ARRIVING AT A DECISION RULE}

The adaptive decision rule in which the use of the characterization data will be embedded is as follows:

"If retrieval is aborted after the top $\mathrm{X}$ inches are removed, or if a leak is detected before retrieval is begun, an inventory based on characterization data on layer-by-layer amounts of $\mathrm{Sr}$ will be employed in conjunction with the latest heat balance studies to compute the heat generation rate of the material remaining in the tank. If the heat generation is below $40,000 \mathrm{Btu} / \mathrm{hr}$, water addition will tentatively cease. If the calculated heat generation is above $40,000 \mathrm{Btu} / \mathrm{hr}$, a model using characterization data on layer by layer values for $\mathrm{Sr}$ and for wet and dry thermal conductivities will be employed to calculate the water addition and ventilation policy (expressed in terms of a cycle internal of $\mathbf{Q}$ days, the amount $\mathbf{R}$ of water that will be added at each cycle, and $S$ number of days of active ventilation for each cycle) required to keep the tank wall temperature below a predetermined safety limit. When the policy defined by $\mathbf{Q}, \mathbf{R}$, and $\mathbf{S}$ is implemented, the tank waste temperatures will be monitored, and the quantitative policy will be adjusted as necessary to maintain temperatures within the required limits."

\section{A7.0 OPTIMIZNG THE DESIGN}

Qualitative discussions suggest that beta scans (or ${ }^{90} \mathrm{Sr}$ measurement) on the extruded sludge core are sufficient for defining Sr layering, and that standard methods for measuring thermal conductivity (wet and dry) would suffice if these were applied separately to composites formed for each core segment (yielding averages that apply to each 19 in. segment) from a single core of the sludge.

Historical use of the model has assumed thermal conductivity values in the range 0.25-0.5 Btu/hr-ft- ${ }^{\circ} \mathrm{F}$. Accordingly, determining actual thermal cr ${ }^{\prime}$ ductivity even as crudely as to the nearest 0.1 would be a useful improvement on these assumptions. Permeability can be defined as the re-absorption percentage for a dried waste sample. The relatively inexact methods for arriving at this request for modest-resolution characterization data are consistent with the non-critical use to which these data will be put in setting initial, tentative water addition rates in the event of aborted retrieval of the sludge or detection of a leak before 
retrieval. It is understood that the initial, tentative water addition rates will be subject to adjustment based on real-time monitoring of actual temperatures.

The requested data precision is less than that anticipated for other purposes, so the data request from WTSP will constitute only a small fractional increment to the total characterization cost. For this reason, there is not much cost savings to be anticipated from a more detailed and quantitative calculation of the data requirements.

The data request from the safety group could be specified more formally and narrowly if parameter sensitivities and predictive power of the thermal model were studied in greater detail. This is not warranted for tank 241-C-106. However, it may be worth pursuing for other tank situations and characterization efforts. 
APPENDIX B

IDENTIFICATION OF MEASURES FOR RETRIEVAL PROJECT

B-1 
WHC-EP-0723

This page intentionally left blank.

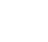




\section{APPENDIX B: IDENTIFICATION OF MEASURES FOR RETRIEVAL PROJECT}

Tables B-1 and B-2 summarize the data needs and justifications for the Retrieval project. Measures of concern were indicated where appropriate. A measure of concern generally represents a point where decisions may change the program's designs and processes. Limits are sometimes indicated to show bounds of tolerance.

The tables serve as reference to defining error tolerance (Section 3.3) and designing the revised sampling and analysis plan (Chapter 5). Measures and limits of concern reflect the point around which changes in decisions are made in each program elements' program. Retrieval is interested in bounding conditions, not average properties of the waste; bounding estimates are typically called tolerance intervals and would be reported as X\% confidence that $Y \%$ of the population of fixed volumes has a result less than the reported value. The measure of concern reported by Retrieval reflects their need to get this type of general knowledge.

A similar DQO process as shown in Appendix A was also documented for Retrieval (Peffers 1993). As mentioned in Chapter 3, these 12 parameters were used conservatively in a design effort initiated in August 1993. As the sampling analyses are completed (expected to be September 1994), the design parameters will be evaluated for overall conservatism. 
Table B.1. Retrieval's Engineering and Design Data Needs for SST 241-C-106

\begin{tabular}{|c|c|c|c|c|}
\hline \multicolumn{5}{|c|}{$\begin{array}{c}\text { RETRIEVAL ENGINEERING \& DESIGN DATA NEEDS: CORE SAMPLE ANALYSIS } \\
\text { AND JUSTIFICATION }\end{array}$} \\
\hline $\begin{array}{c}\text { DESION } \\
\text { INFORMATION } \\
\text { REQUIRED }\end{array}$ & MEASURE & JUSTIFICATION & $\begin{array}{c}\text { MMPACT OF } \\
\text { INSUFFICIENT DATA }\end{array}$ & $\begin{array}{l}\text { LMMTS OF } \\
\text { CONCBRN, } \\
\text { ACCURACY, } \\
\text { AND } \\
\text { PRBCISION }\end{array}$ \\
\hline 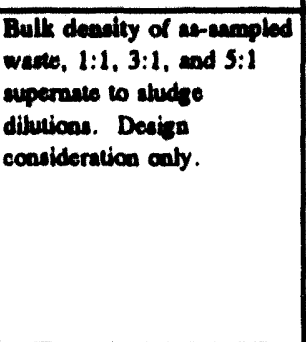 & 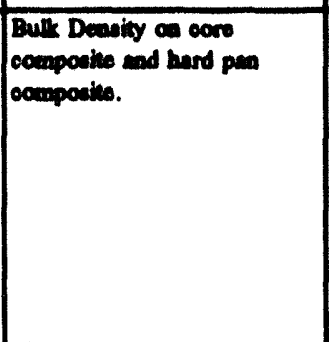 & 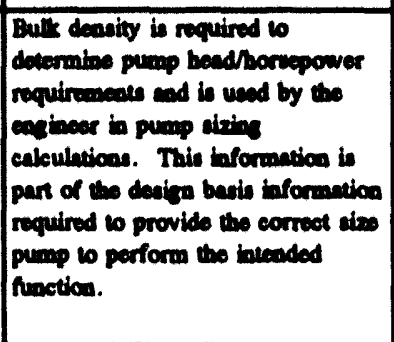 & 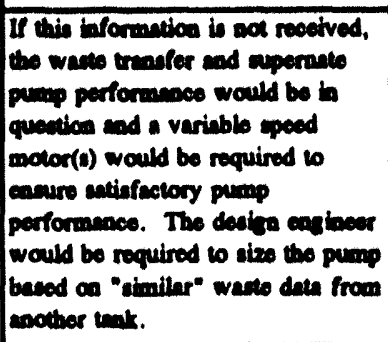 & 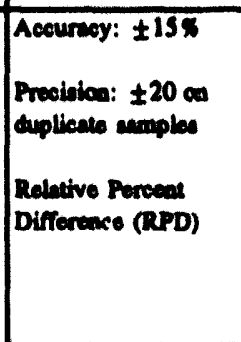 \\
\hline 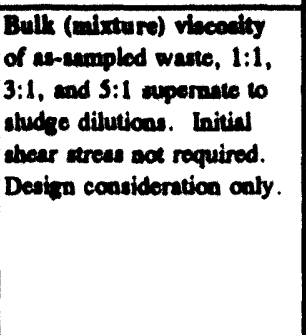 & 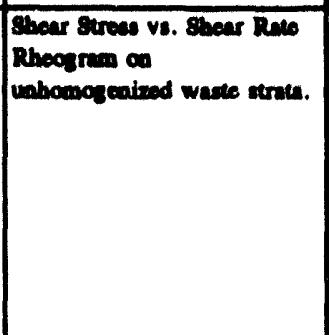 & 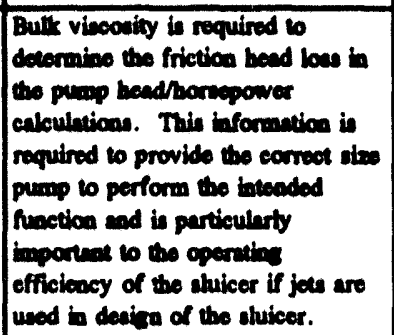 & 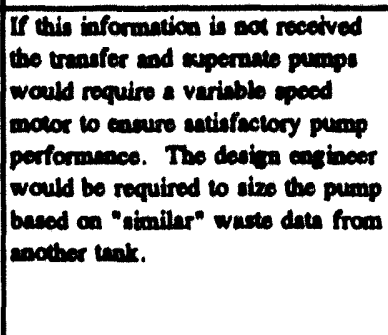 & $\begin{array}{l}\text { Aceuricy: } \pm 15 \pi \\
\text { Procinion: } \pm 20 \text { RPD } \\
\text { on duplicete samplea }\end{array}$ \\
\hline $\begin{array}{l}\text { Bulk fluoride/ebloride } \\
\text { concentration of as- } \\
\text { anmpled waste, } 1: 1,3: 1 \text {, } \\
\text { and } 5: 1 \text { superante to sludge } \\
\text { dilutions. } \\
\text { Design and requlatory } \\
\text { considerations. }\end{array}$ & $\begin{array}{l}\text { Ion Chromatography on } \\
\text { water leach of biquid } \\
\text { composine, core componite, } \\
\text { and hard pan componite. }\end{array}$ & 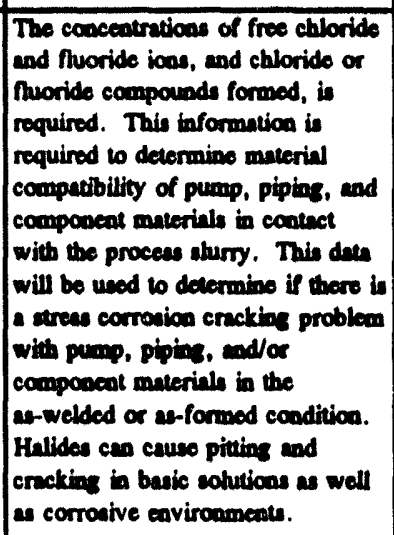 & 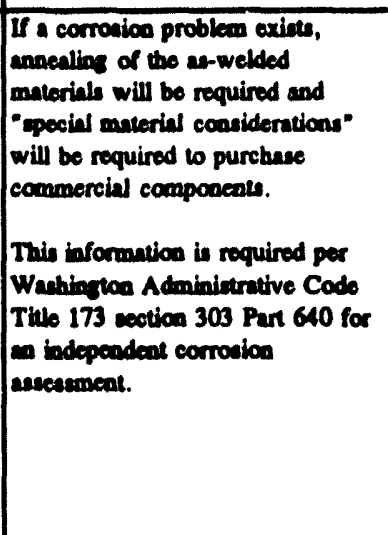 & 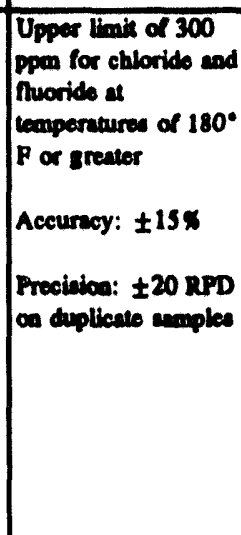 \\
\hline 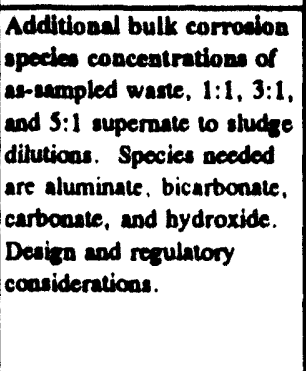 & 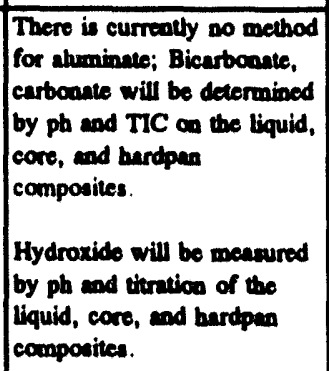 & $\begin{array}{l}\text { Corrosion rate/ epecies } \\
\text { ideatification concentrations are } \\
\text { required to determine material } \\
\text { compatibility of system materials. }\end{array}$ & 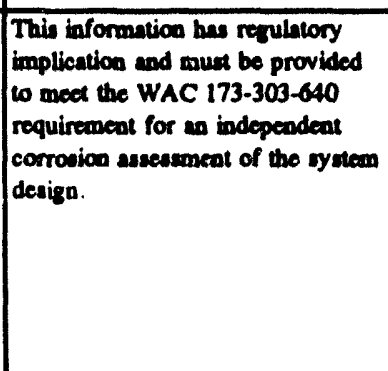 & $\begin{array}{l}\text { Accuracy: } \pm 15 \% \\
\text { Procirion: } \pm 20 \text { RPD } \\
\text { on duplicate amples }\end{array}$ \\
\hline
\end{tabular}


Table B.1. Retrieval's Engineering and Design Data Needs for SST 241-C-106

\begin{tabular}{|c|c|c|c|c|}
\hline \multicolumn{5}{|c|}{$\begin{array}{r}\text { RETRIEVAL ENGINEERING \& DESIGN DATA NEED } \\
\text { AND JUSTIFICATION }\end{array}$} \\
\hline 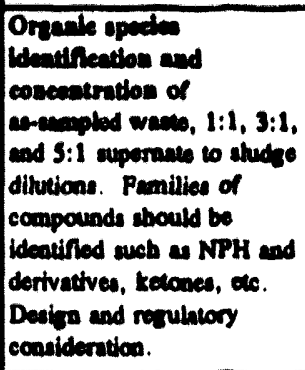 & 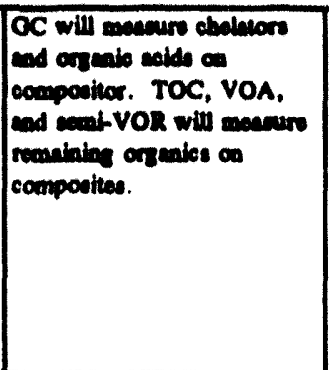 & 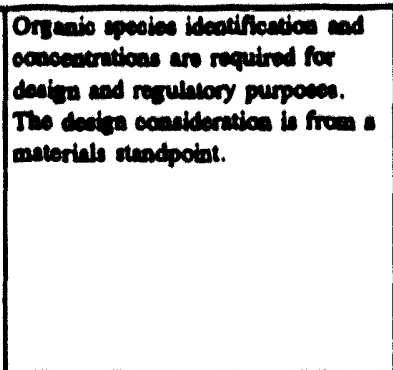 & 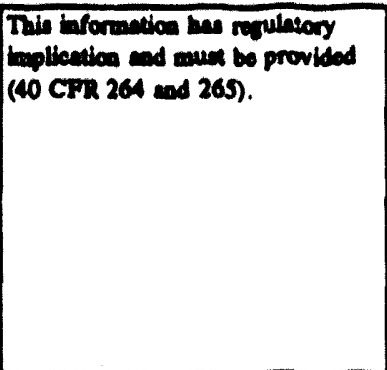 & 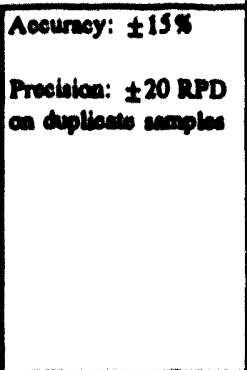 \\
\hline 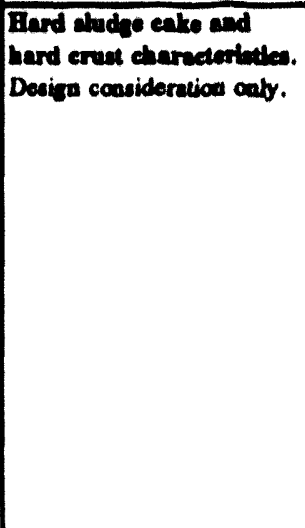 & 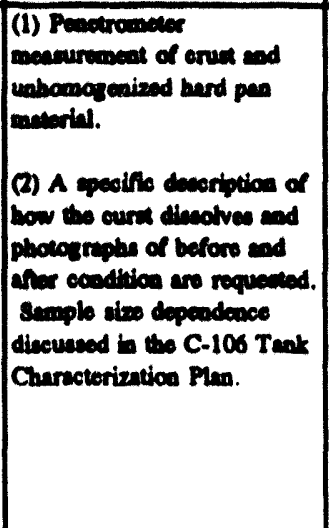 & 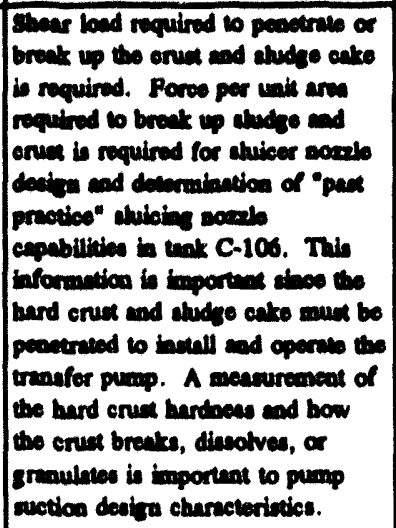 & 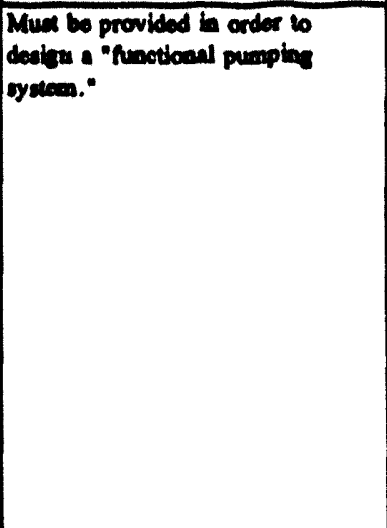 & 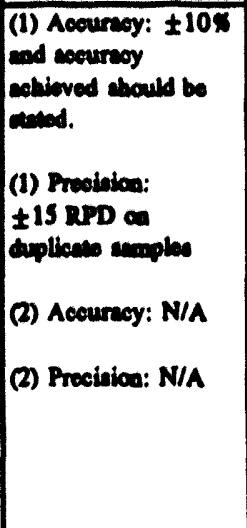 \\
\hline 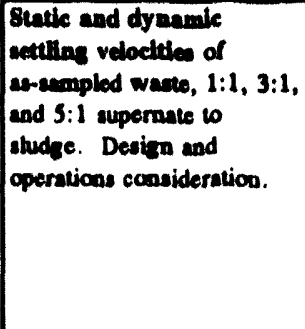 & 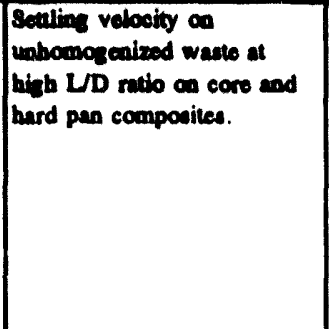 & 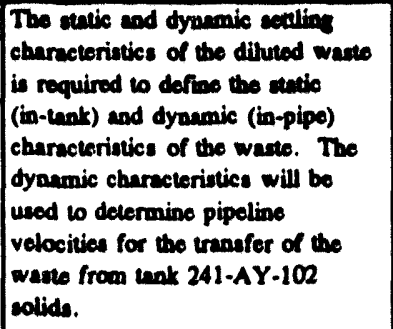 & 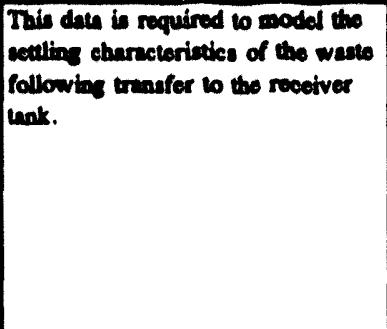 & 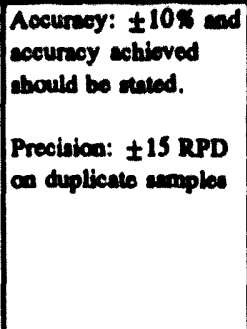 \\
\hline $\begin{array}{l}\text { Purtiele alse and } \\
\text { diteribution } \\
\text { Design considention only. }\end{array}$ & $\begin{array}{l}\text { TCP will documeal that } \\
\text { there is no curreat method } \\
\text { for this. }\end{array}$ & 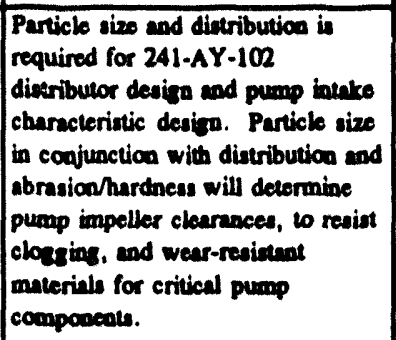 & 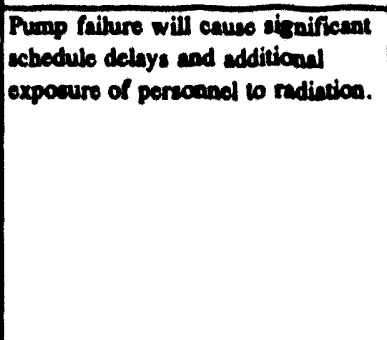 & N/A \\
\hline $\begin{array}{l}\text { Erodion teat (measure of } \\
\text { abraciveceses) deaign } \\
\text { consideration onty. }\end{array}$ & $\begin{array}{l}\text { Abrasiveseas (in develop.) } \\
\text { of core componite. }\end{array}$ & 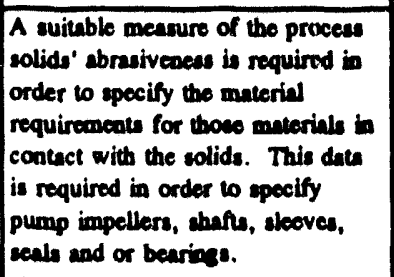 & $\begin{array}{l}\text { Pump fallure will cause significenat } \\
\text { echedub delays med edditional } \\
\text { expoenure of pernosecl to radintion. }\end{array}$ & $\begin{array}{l}\text { Accurncy: } \pm 15 \\
\text { Prociaion: } \pm 20 \text { RPD } \\
\text { os duplicale enmples }\end{array}$ \\
\hline
\end{tabular}


Table B.2. Retrleval's HVAC System Data Needs for SST 241-C-106

\begin{tabular}{|c|c|c|c|c|}
\hline \multicolumn{5}{|c|}{$\begin{array}{c}\text { RETRIEVAL HVAC SYSTEM DATA NEEDS: AIRSTREAM SAMPLE ANALYSIS AND } \\
\text { JUSTIPICATION }\end{array}$} \\
\hline $\begin{array}{l}\text { NFORMATION } \\
\text { REQUIRED }\end{array}$ & MBASURA & JUSTIFICATION & $\begin{array}{c}\text { MMPACT OF } \\
\text { NNSUFFICIBNT } \\
\text { DATA }\end{array}$ & $\begin{array}{c}\text { LDMITS OF } \\
\text { CONCBRN, } \\
\text { ACCURACY, AND } \\
\text { PRBCISION }\end{array}$ \\
\hline 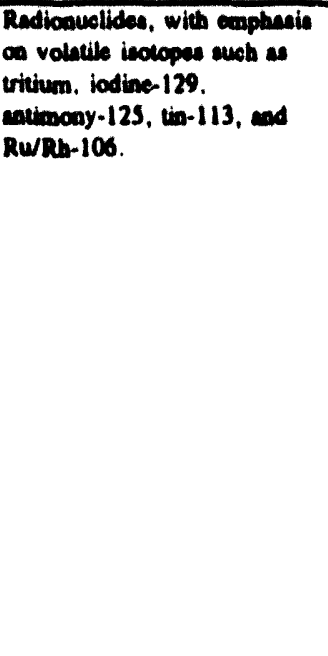 & 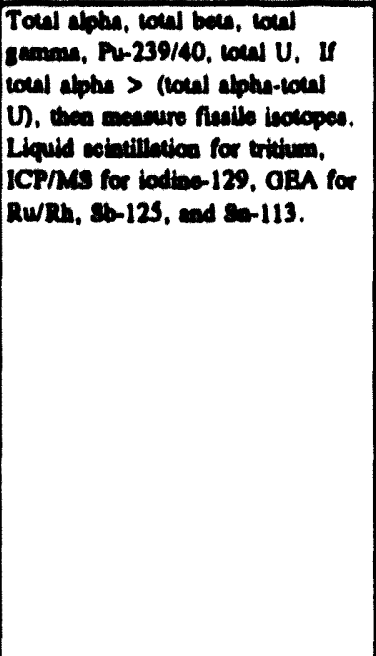 & 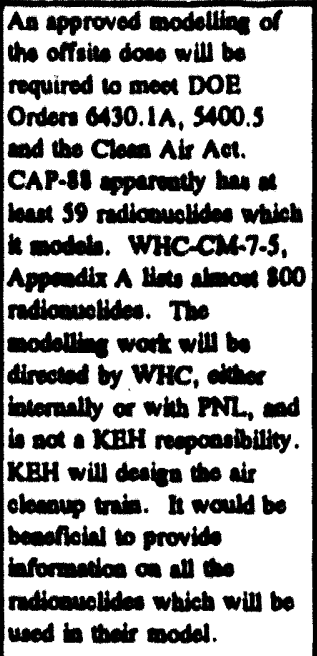 & 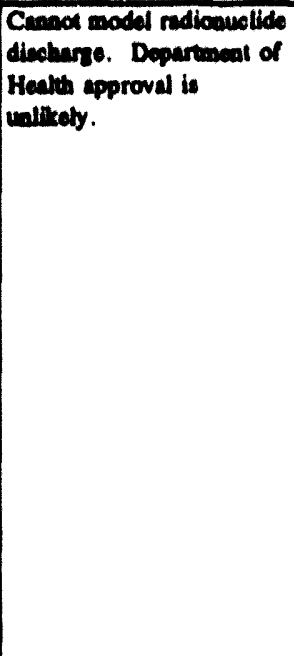 & $\begin{array}{l}\text { Accurncy: } \pm 10 \pi \\
\text { Precision: } \pm \text { 1S RPD an } \\
\text { duplicenes amples }\end{array}$ \\
\hline 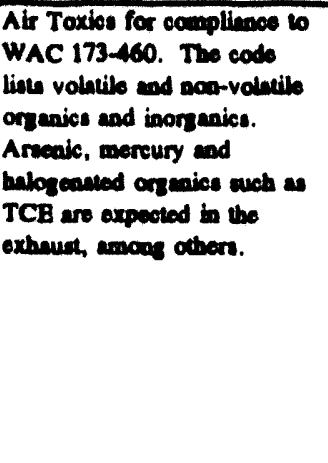 & 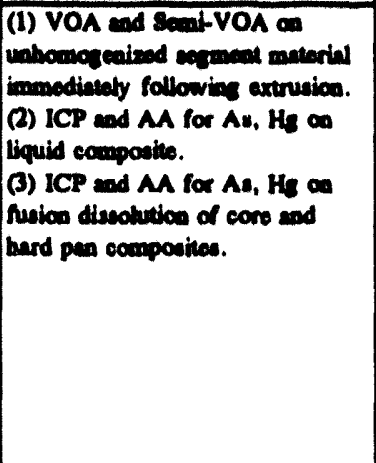 & 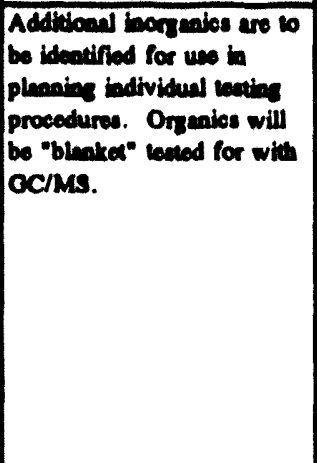 & 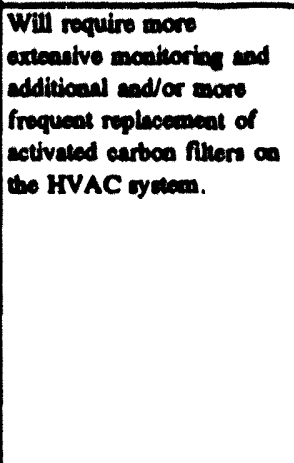 & 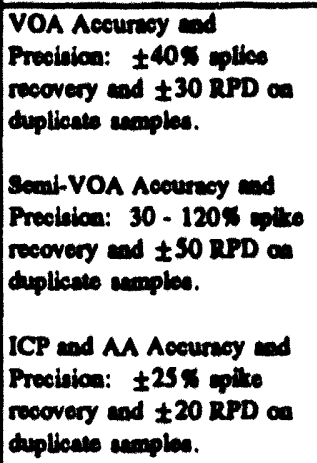 \\
\hline 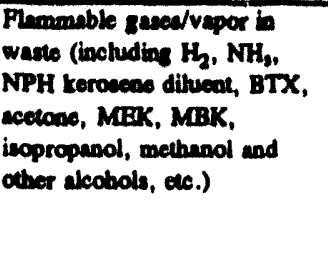 & 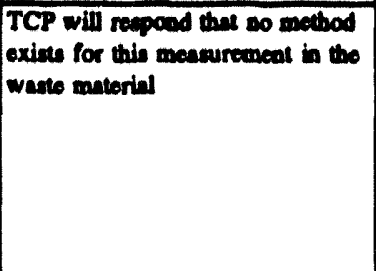 & 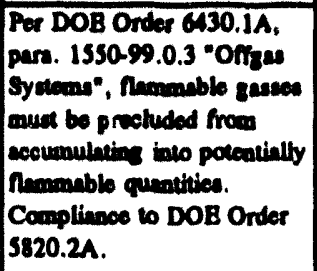 & 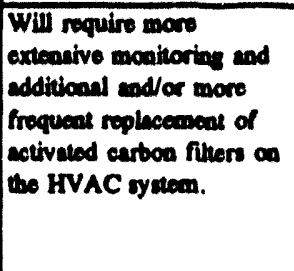 & N/A \\
\hline
\end{tabular}




\section{DISTRIBUTION}

Number of copies

\section{OEESITE}

4

2

\section{ONSEOE}

11

7
U.S. Department of Energy

EM-35, Trevion II

Washington, D.C. 20585

Harry Calley (2)

John C. Tseng

Dan Goodman

MACTEC

Stan Blacker

Roland Raco

U.S. Department of Energy Bichland Bield Office

G. E. Bishop

R3-72

R. F. Christensen

R. E. Gerton

A4-02

R. G. Harwood (5)

A4-02

P. R. Hernandez

R3-72

W. R. Wrzinskd

R3-72

Public Reading Room

R3-72

A1-65

Pacific Northwest Laboratory

C. M. Anderson

K7-34

B. M. Johnson

K1-78

S. G. McKinley

P7-22

M. Peffers

K7-94

B. A. Pulsipher

K7-34

J. Scott

P7-85

PNL Technical Files 


\section{DISTRIBUTION (continued)}

\section{Number of copies}

\section{ONSTUE}

W. T. Alumbal

H. Babad

R2-78

K. B. Bell

R2-12

O. T. Berlin

LO-18

J. B. Billetdenux

R2-08

R. J. Blanchard

R1-17

D. C. Board

S1-57

O. M. Christensen

H4-21

C. DeFigh-Price

R2-31

C. J. Forbes

R1-08

J. C. Fulton

R2-31

K. A. Gasper

R2-08

C. S. Haller

R2-12

D. W. Hamilton

T6-02

H. D. Harmon

R2-52

J. P. Harris III

S4-55

J. M. Henderson

S4-55

M. N. Islam

R3-08

G. A. Johnson

R3-35

N. W. Kirch

R2-11

C. A. Kuhlman

B3-03

J. R. Mobley

R2-88

A. F. Noonan

R2-12

R. S. Popielarczyk

R1-30

D. N. Price

S2-48

R. E. Raymond

R2-54

K. G. Squires

S4-55

O. S. Wang (15)

R2-78

W. I. Winters

T6-50

W. F. Zuroff

R2-14

Document Processing and Distribution (2)

L8-15

Central Files

L8-04

Information Release Administration 

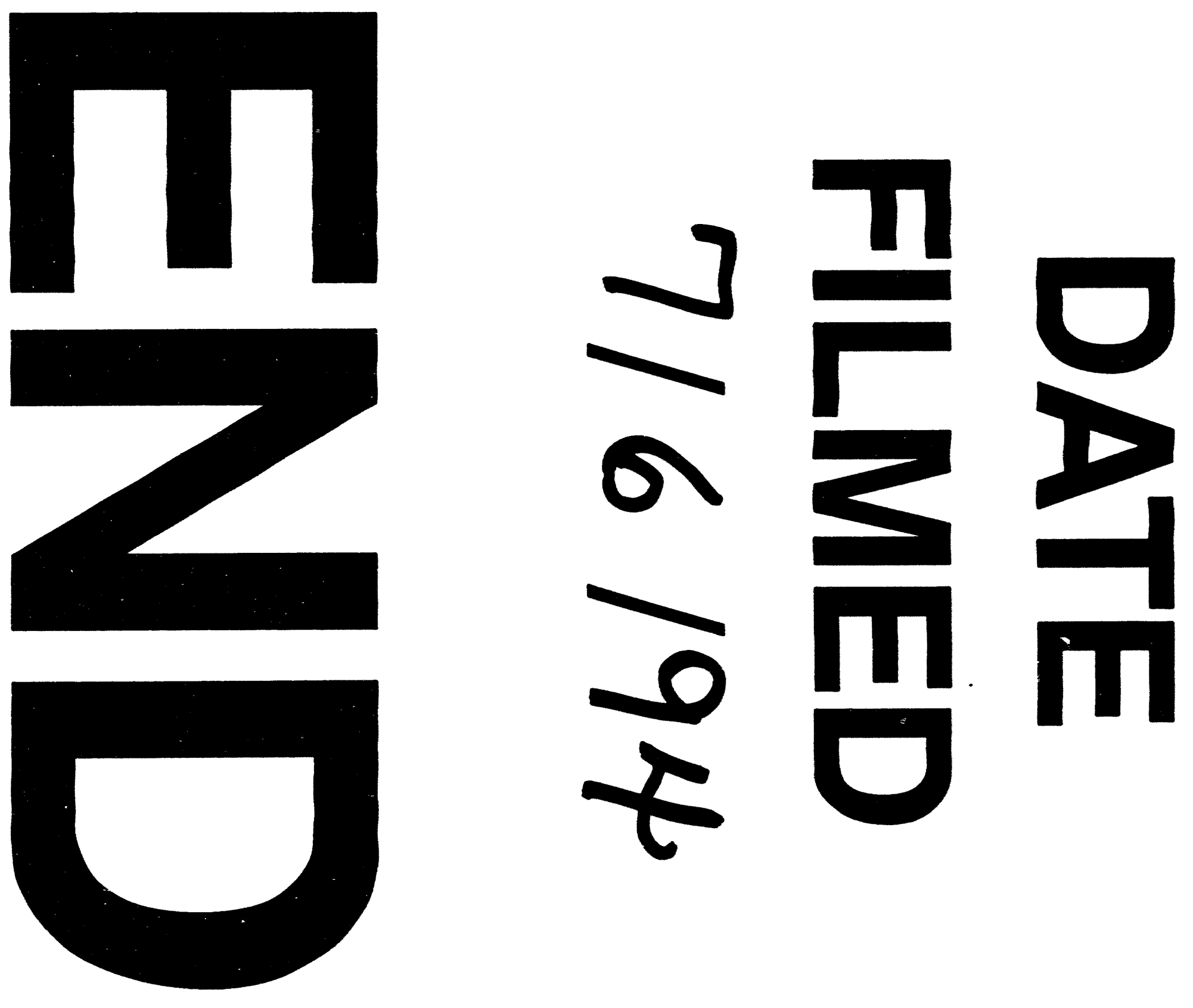
